\title{
CO Sense and Release Flavonols: Progress toward the Development of an Analyte Replacement PhotoCORM for Use in Living Cells
}

\author{
Marina Popova, Tatiana Soboleva, Abby D. Benninghoff, and Lisa M. Berreau*
}

Cite This: ACS Omega 2020, 5, 10021-10033

Read Online

ABSTRACT: Carbon monoxide (CO) is a signaling molecule in humans. Prior research suggests that therapeutic levels of $\mathrm{CO}$ can have beneficial effects in treating a variety of physiological and pathological conditions. To facilitate understanding of the role of $\mathrm{CO}$ in biology, molecules that enable fluorescence detection of $\mathrm{CO}$ in living systems have emerged as an important class of chemical tools. A key unmet challenge in this field is the development of fluorescent analyte replacement probes that replenish the $\mathrm{CO}$ that is consumed during detection. Herein, we report the first examples of $\mathrm{CO}$ sense and release molecules that involve combining a common CO-sensing motif with a light-triggered CO-releasing flavonol scaffold. A notable advantage of the flavonol-based $\mathrm{CO}$ sense and release motif is that it is trackable via fluorescence in both its pre- and postsensing (pre-CO release) forms. In
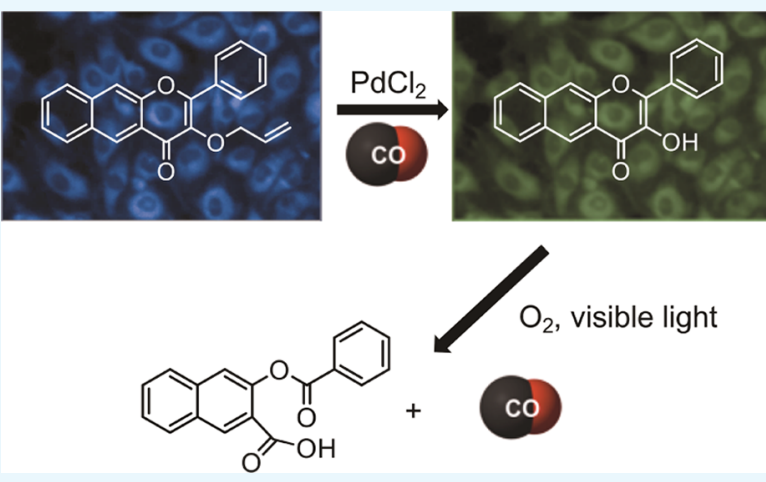
vitro studies revealed that the $\mathrm{PdCl}_{2}$ and $\mathrm{Ru}(\mathrm{II})$-containing CORM-2 used in the $\mathrm{CO}$ sensing step can result in metal coordination to the flavonol, which minimizes the subsequent $\mathrm{CO}$ release reactivity. However, $\mathrm{CO}$ detection followed by $\mathrm{CO}$ release is demonstrated in living cells, indicating that a cellular environment mitigates the flavonol/metal interactions.

\section{INTRODUCTION}

Carbon monoxide (CO) is a signaling molecule in humans that is generated endogenously via the enzyme-catalyzed breakdown of heme. ${ }^{1}$ There is significant current interest in understanding the biological effects of $\mathrm{CO}$ as well as in advancing its potential use in improving human health. ${ }^{2-10}$ Related to these goals, significant recent research has focused on the development of systems for monitoring the presence and concentration of $\mathrm{CO}$ in living systems. Many methods for the detection of $\mathrm{CO}$ have been reported, including gas chromatography, Fourier transform infrared (FTIR), chromogenic detection, electrochemical and myoglobin assays, and commercial CO detectors. ${ }^{11-18}$ However, many of these approaches are not suitable for real-time detection of $\mathrm{CO}$ in living systems. Recently, fluorescence detection-based probes have emerged as useful tools to monitor and detect $\mathrm{CO}$ in biological systems. ${ }^{19-46}$ Three primary types of fluorescent molecular CO sensors have been developed. Palladacycle compounds, such as COP-1 (Figure 1a), exhibit quenched fluorescence for the organic fluorophore due to the presence of $\mathrm{Pd}(\mathrm{II})$. Loss of the metal ion following palladium-mediated carbonylation with $\mathrm{CO}$ results in the formation of a detectable organic fluorophore. ${ }^{21-28}$ A second class of $\mathrm{CO}$ sensors function via the $\operatorname{Pd}(0)$-mediated cleavage of an allyl propyl ether or carbonate appendage. ${ }^{29-46}$ This Tsuji-Trost reactivity follows the approach used for sensing palladium in cellular environments. ${ }^{47-49}$ The first example of this type of sensor, PCO-1, was reported by Pal, et al. ${ }^{29}$ and resulted in the formation of a coumarin fluorophore (Figure $1 \mathrm{~b}$ ). A third type of proposed $\mathrm{CO}$ sensor is based on the CO-mediated reduction of an aryl nitro moiety to a primary amine. ${ }^{50-53}$ An example of a sensor in this class is the naphthalimide-based sensor COFP (Figure 1c). ${ }^{50}$ Notably, these sensors have recently been shown to sense only CORM-2 or CORM-3, but not $\mathrm{CO}$ in general. ${ }^{53}$ Outside these three general classes of compounds, a few additional types of fluorescent $\mathrm{CO}$ sensors have been reported. ${ }^{20,54,55}$

The fluorescent $\mathrm{CO}$ probes reported to date share a common drawback. Specifically, the consumption of an equivalent of $\mathrm{CO}$ is required during the process of $\mathrm{CO}$ sensing. CO-binding metal complexes offer the possibility of colorimetric, spectrochemical, or electrochemical CO sensing without consumption of the analyte, if the CO-binding reaction is reversible. ${ }^{56-67}$ However, CO-sensing metal complexes that combine CO-binding reversibility with various other useful properties, such as selectivity over other bioanalytes (e.g., reactive oxygen species and reactive nitrogen species), are yet to be developed. Additional challenges in

Received: January 29, 2020

Accepted: April 8, 2020

Published: April 23, 2020 
(a) Palladacyle

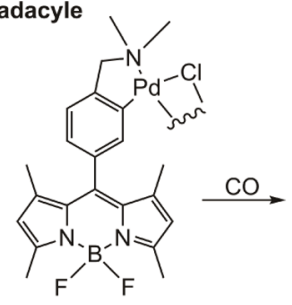

COP-1

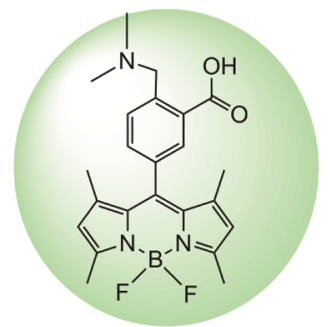

(b) Tsuji-Trost

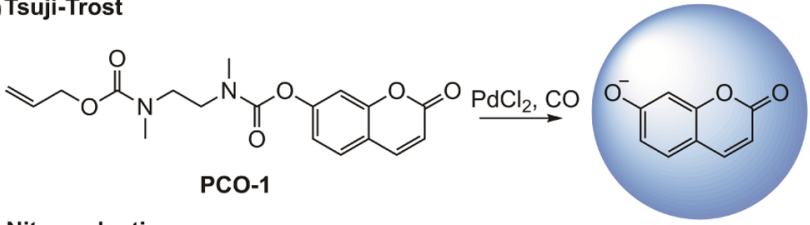

(c) Nitro reduction
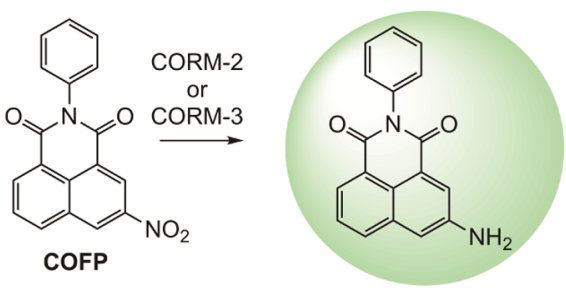

Figure 1. Types of fluorescent sensors $(\mathrm{a}-\mathrm{c})$ for detection of $\mathrm{CO}$ or CORMs in biological systems. The coloration of the circles indicates the wavelength of the fluorescent emission.

using metal-based $\mathrm{CO}$ sensors include the possibility of redox activity of the metal center and/or interactions of the metal center with biological molecules, including proteins and biothiols. $^{68,69}$

Analyte replacement metal-free molecular fluorescent probes have recently been reported in the context of $\mathrm{H}_{2} \mathrm{~S}$ and formaldehyde (FA) sensing (Figure 2a,b). ${ }^{70,71}$ The goal of such probes is to enable fluorescent analyte sensing while not disrupting the cellular homeostasis of the analyte. As shown in Figure $2 \mathrm{a}, \mathrm{H}_{2} \mathrm{~S}$ sensing via reduction of an aryl azide, followed by self-immolative reactivity involving a linker, results in the release of carbonyl sulfide, which as a substrate for carbonic anhydrase enzymes can result in the regeneration of $\mathrm{H}_{2} \mathrm{~S}$. The FA sensor outlined in Figure $2 \mathrm{~b}$ exhibits more synchronous activity, with the capture of the formaldehyde resulting in a structural change that results in subsequent release of a fluorophore and the analyte. Both types of analyte replacement fluorescent probes have been used in cell-based studies, with the FA probes offering the opportunity to detect FA both intracellularly and inside lysosomes.

Development of molecular analyte replacement probes for $\mathrm{CO}$ requires the design of a detectable $\mathrm{CO}$ sensing response coupled with a CO-releasing motif. Herein, we report the progress toward the development of the first analyte replacement fluorescent probes for $\mathrm{CO}$. These probes are comprised of a flavonol-based photoCORM with an allyl ether (1, Figure 2c) or allyl propyl formate (2) motif. CO detection is enabled via Tsuji-Trost-type reactivity in the presence of Pd(II). Our hypothesis was that the CO sensing reaction would result in the formation of the parent flavonol Flav-1 $\mathbf{1}^{72}$ which is fluorescent and trackable in cells. Visible light-induced $\mathrm{CO}$ release from Flav-1 would then replenish the $\mathrm{CO}$ used in the sensing reaction, thus leaving the overall $\mathrm{CO}$ level unchanged. Results of in vitro experiments demonstrate that

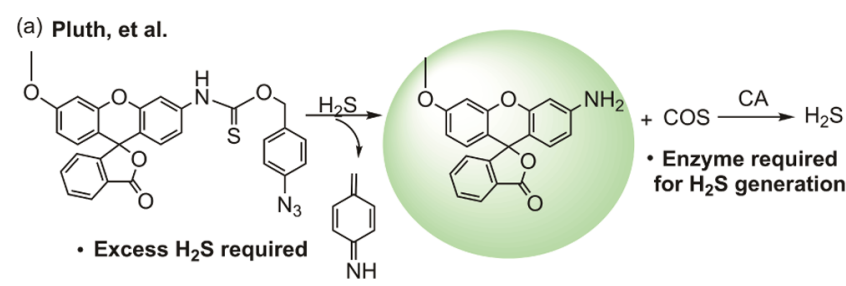

(b) Wang, et al.

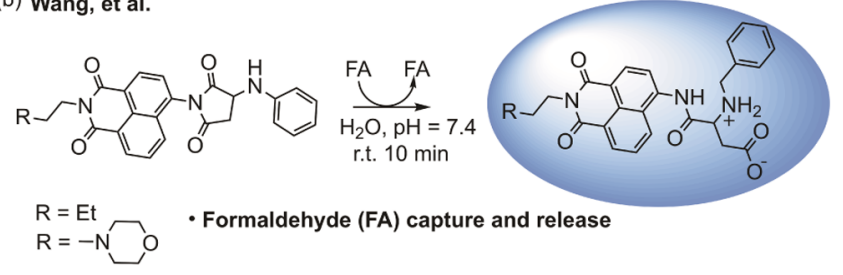

(c) This work

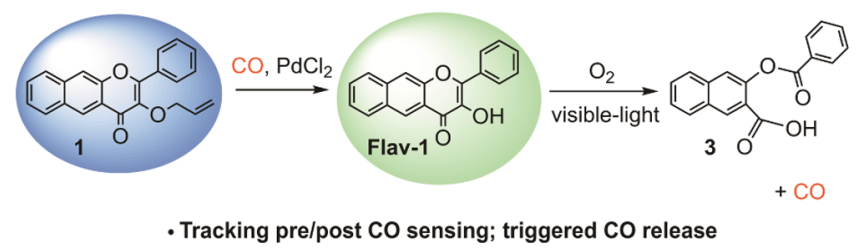

Figure 2. Analyte replacement probes for (a) $\mathrm{H}_{2} \mathrm{~S}$ and (b) formaldehyde (c) CO sense and release molecule developed in this work. The coloration of the spheres indicates the wavelength of the fluorescent emission.

the Flav-1 generated in the Tsuji-Trost-type CO sensing reaction (using either CORM-2 or CO gas as the $\mathrm{CO}$ source) interacts with $\mathrm{Pd}(\mathrm{II})$ and/or CORM-2 fragments in the reaction mixture, minimizing the subsequent $\mathrm{CO}$ release reactivity. However, cell-based studies in human umbilical vein endothelial cells (HUVECs) demonstrate that the cellular environment mitigates the flavonol/metal interactions enabling the desired $\mathrm{CO}$ sense and release reactivity.

\section{RESULTS AND DISCUSSION}

Synthesis and Characterization of 1 and 2. Compounds 1 and 2 were prepared from Flav-1 via one-step reactions with commercially available allyl bromide or allyl chloroformate under basic conditions (Scheme 1). Both were characterized by ${ }^{1} \mathrm{H}$ and ${ }^{13} \mathrm{C}\left\{{ }^{1} \mathrm{H}\right\}$ NMR, FTIR, and mass spectrometry (Figures $\mathrm{S} 1-\mathrm{S} 8$ ). A single crystal of $\mathbf{1}$ suitable for $\mathrm{X}$-ray crystallography was obtained from dimethyl sulfoxide (DMSO). Details of the X-ray data collection and solution are available in the Supporting Information (Tables S1 and S2). A representation of the structure is shown in Figure 3. The

Scheme 1. Synthesis of CO-Sensing Flavonol Derivatives<smiles>C=CCOC(=O)Oc1c(-c2ccccc2)oc2cc3ccccc3cc2c1=O</smiles> 


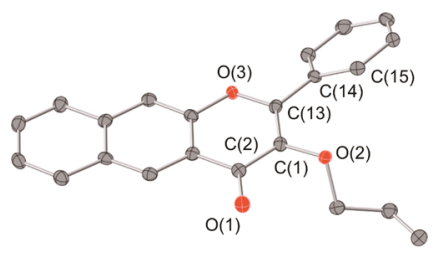

Figure 3. Representation of the X-ray structure of $\mathbf{1}$.

naphthyl-fused 3-hydroxy-4-pyrone ring structure is nearly planar with the phenyl appendage twisting slightly out of this plane. We note that $\mathbf{1}$ has bond lengths and angles very similar to those of Flav-1 (Table S2). ${ }^{72}$

The spectroscopic properties of $\mathbf{1}$ and $\mathbf{2}$ were evaluated and compared with those of Flav-1 and the CO-release product 3. The absorption bands of $\mathbf{1}$ and $\mathbf{2}$ in DMSO are centered at 370 and $380 \mathrm{~nm}$, respectively (Figure 4). Excitation into these bands produces emission features with maxima at $\sim 463$ and $458 \mathrm{~nm}$, respectively, for 1 and 2 (Figure 4). Flav-1 has an absorption maximum at $411 \mathrm{~nm}$ and emits with a maximum at $550-600 \mathrm{~nm}$ depending on solvent conditions. ${ }^{73}$ The product of $\mathrm{CO}$ release 3 does not have absorption or emission features in the visible region. ${ }^{72,73}$ Thus, the absorption and emission features of $\mathbf{1}$ and 2 are distinct (Figure 5), indicating that deprotection of $\mathbf{1}$ or $\mathbf{2}$ to form Flav-1 and the subsequent release of $\mathrm{CO}$ upon illumination to form 3 will be identifiable by both absorption and emission spectroscopy.

Hydrolytic Stability of 1 and 2. The hydrolytic stability of 1 and 2 was evaluated in 40\% DMSO in PBS and in 8\% DMSO in Dulbecco's modified Eagle's medium (DMEM). The intensity of the emission bands of 1 in both solvent mixtures did not change when monitored at $37{ }^{\circ} \mathrm{C}$ for $90 \mathrm{~min}$ (Figure 5a,b). Thus, $\mathbf{1}$ is stable with respect to hydrolysis under conditions relevant to cell culture studies. Compound $\mathbf{2}$ is stable in a solution of $40 \%$ DMSO in PBS $(10 \mathrm{mM}, \mathrm{pH} 7.4)$ over $90 \mathrm{~min}$ of incubation at $37^{\circ} \mathrm{C}$ (Figure 5c). In contrast, in 8\% DMSO in DMEM 2 undergoes hydrolysis with the formation of Flav-1. As shown in Figure 5d, this transformation is evidenced by a decrease in emission intensity at $465 \mathrm{~nm}$ along with an increase in emission at $\sim 600 \mathrm{~nm}\left(\lambda_{\text {ex }}=\right.$ $411 \mathrm{~nm})$, which corresponds to the formation of Flav-1. Additionally, the formation of Flav-1 was identified by the appearance of its characteristic absorption bands at 396 and $413 \mathrm{~nm}$, respectively, upon incubation of 2 in $8 \%$ DMSO in DMEM at $37{ }^{\circ} \mathrm{C}$ after $90 \mathrm{~min}$. Because of the hydrolytic instability of $\mathbf{2}$, further studies of the stability and CO sensing/ releasing properties were limited to investigations of $\mathbf{1}$.

Photostability of $\mathbf{1}$. The photostability of $\mathbf{1}$ in DMSO was evaluated using UV-vis upon illumination with $465 \mathrm{~nm}$ light (5972 lx; Figure S9a) for $1 \mathrm{~h}$. The probe was found to be stable with respect to light for the tested timeline. The $465 \mathrm{~nm}$ light was chosen based on the use of a $460 \mathrm{~nm}$ LED array in cellular studies to induce CO release from Flav-1. ${ }^{74}$ The light stability of 1 was also investigated by ${ }^{1} \mathrm{H}$ NMR in DMSO- $d_{6}$ over the course of $24 \mathrm{~h}$ (Figure S9b) with no change being evident.

Fluorescence Detection of CO Using 1 in 8\% DMSO in DMEM or DMSO. The CO sensing properties of 1 were evaluated in $8 \%$ DMSO in DMEM $(\mathrm{pH}=7.4)$ or DMSO upon treatment with $\mathrm{PdCl}_{2}$ (2 equiv) and CORM-2 (10 equiv) following $90 \mathrm{~min}$ of incubation at $37^{\circ} \mathrm{C}$ under dark conditions. The spectral changes expected with $\mathrm{CO}$ sensing via the TsujiTrost-type reaction were the loss of the emission feature of $\mathbf{1}$ at $\sim 465 \mathrm{~nm}$ and the growth of an emission at $\sim 600 \mathrm{~nm}$ associated with the formation of Flav-1. An increase in absorbance in the region of $400-450 \mathrm{~nm}$ would also be expected for Flav-1 formation. As shown in Figure 6a, an emission at $\sim 560 \mathrm{~nm}\left(\lambda_{\mathrm{ex}}=411 \mathrm{~nm}\right)$ that is produced following treatment of 1 with $\mathrm{PdCl}_{2} / \mathrm{CORM}-2$ in $8 \%$ (v/v) DMSO in DMEM is quenched relative to that expected for complete conversion to Flav-1 (shown vs a $50 \mu \mathrm{M}$ Flav-1 control sample). The absorption spectral features of the same solution (Figure $6 \mathrm{c}$ ) show the presence of a band at $\sim 500 \mathrm{~nm}$ which is red-shifted relative to the absorption features of Flav1 under the same conditions. The absorption spectrum produced upon treatment of 1 with $\mathrm{CORM}-2 / \mathrm{PdCl}_{2}$ also shows a high baseline absorbance, consistent with possible particulate formation. Based on literature precedent discussed below, these emission and absorption features suggest the formation of $\mathrm{Pd}(\mathrm{II})$ and/or $\mathrm{Ru}(\mathrm{II})$ complexes of Flav-1 in the deprotection $\mathrm{CO}$ sensing reaction mixture. We note that we have previously reported that Flav-1 can exist in its anionic form (deprotonated at the 3-hydroxy position) in buffer/media solutions at $\mathrm{pH}=7.4$, which likely enhances its metal coordination properties. ${ }^{73}$

To further evaluate the potential formation of $\mathrm{Pd}(\mathrm{II})$ or $\mathrm{Ru}$ (II) coordination complexes of Flav-1 in the Tsuji-Trosttype CO-sensing reaction of $\mathbf{1}$, additional control experiments were performed. Shown in Figure $6 \mathrm{a}, \mathrm{c}$ are the emission and absorption spectral features of Flav-1 in 8\% DMSO in DMEM in the presence of added $\mathrm{PdCl}_{2}$ or CORM-2. Notably, the emission of Flav-1 (Figure 6a) is nearly fully quenched in
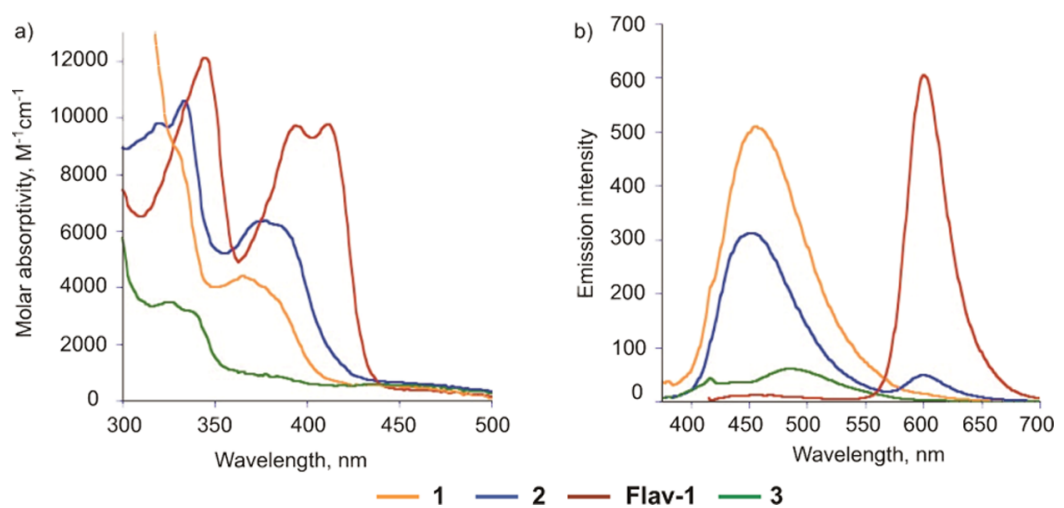

Figure 4. Absorption (a) and emission (b) spectral data for 1-3 and Flav-1 in DMSO. 

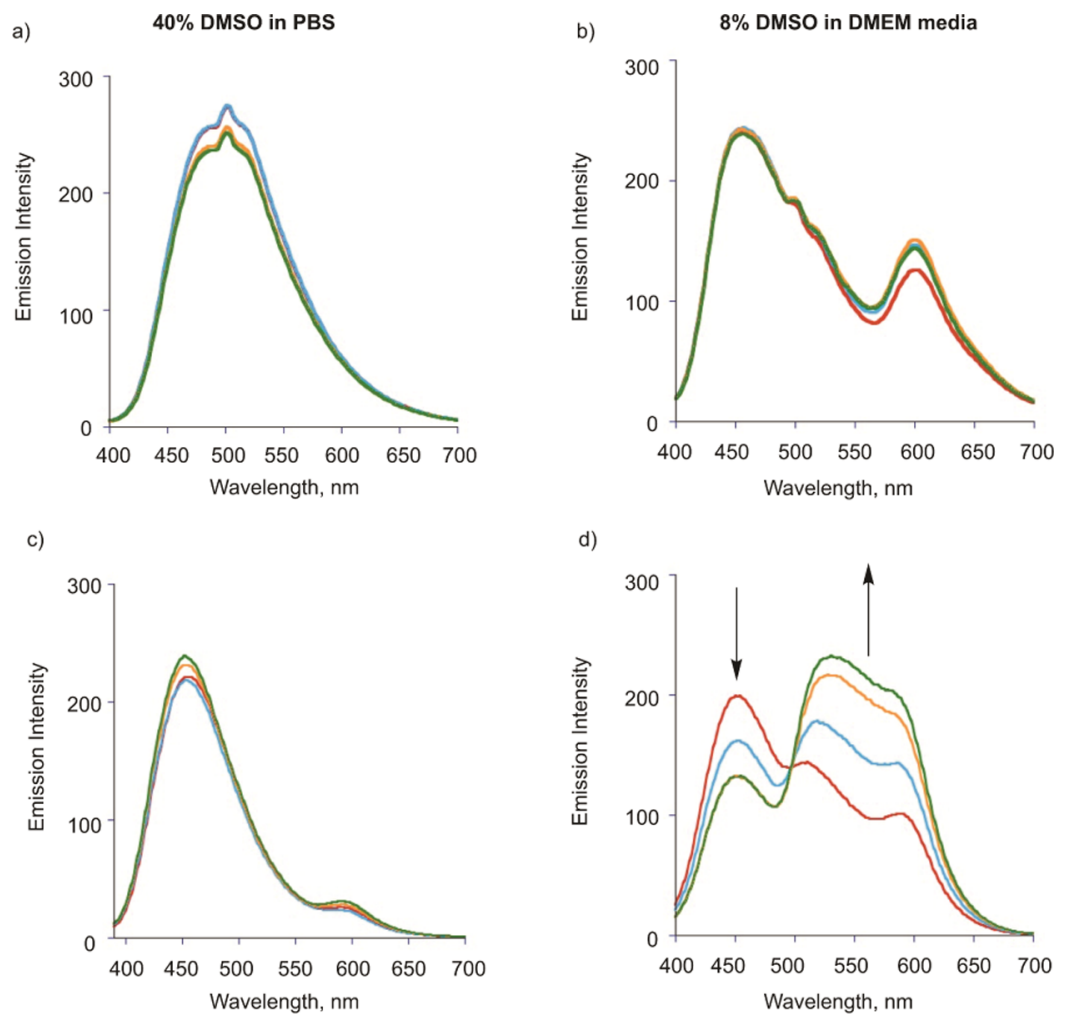

$-15 \mathrm{~min}-30 \mathrm{~min}-60 \mathrm{~min}-90 \mathrm{~min}$

Figure 5. Changes in the emission spectra of $\mathbf{1}((\mathrm{a}, \mathrm{b}))$ and $\mathbf{2}((\mathrm{c}, \mathrm{d}))$ in $40 \%$ DMSO in PBS or $8 \%$ DMSO in DMEM upon incubation at $37^{\circ} \mathrm{C}$ for $90 \min \left(\lambda_{\mathrm{ex}}=370 \mathrm{~nm}\right)$.
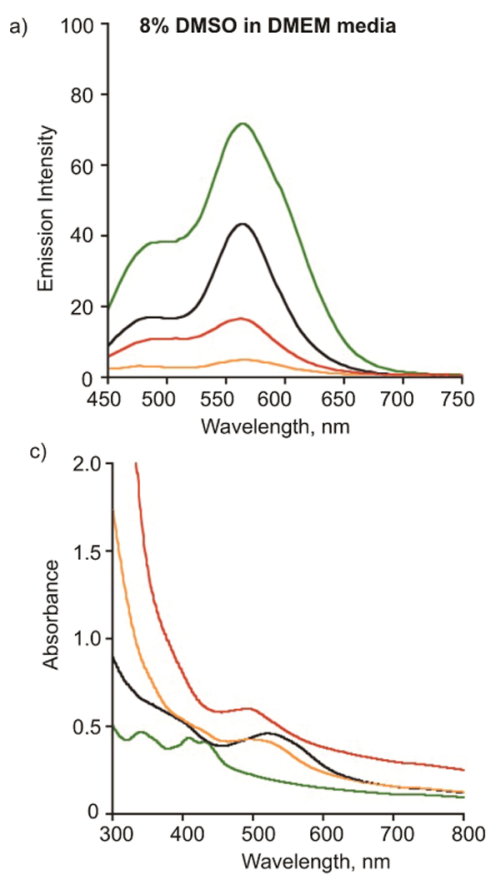

Flav-1 Flav-1 + CORM-2
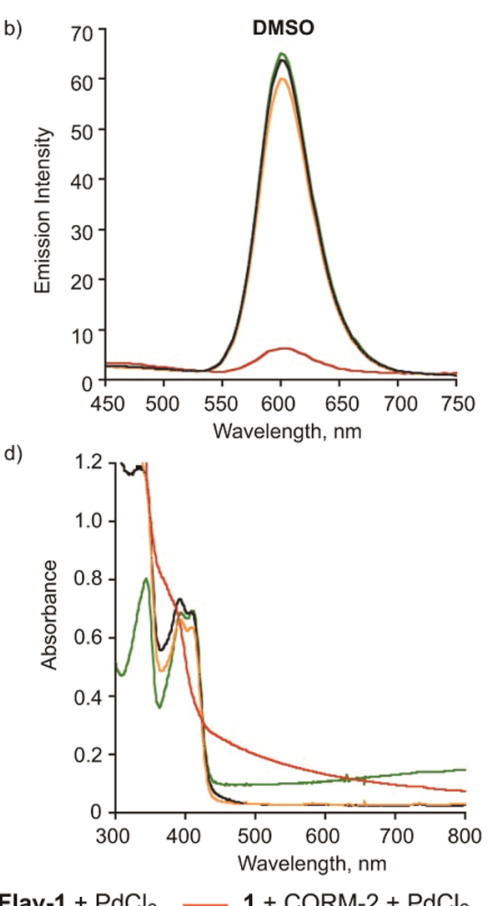

Figure 6. Emission (top) and absorption (bottom) spectra produced upon treatment of Flav-1 (50 $\mu \mathrm{M})$ with $\mathrm{PdCl}_{2}(100 \mu \mathrm{M})$ or CORM-2 (500 $\mu \mathrm{M})$ in $(\mathrm{a}, \mathrm{c}) 8 \%$ DMSO in DMEM and $(\mathrm{b}, \mathrm{d})$ DMSO after $90 \mathrm{~min}$ at $37^{\circ} \mathrm{C}\left(\lambda_{\mathrm{ex}}=411 \mathrm{~nm}\right)$. In each spectrum, the features produced in the COsensing Tsuji-Trost deprotection reaction of 1 are shown. A comparative control spectrum of Flav-1 is shown at the concentration (50 $\mu \mathrm{M})$ anticipated for full conversion of $\mathbf{1}$ to Flav-1 in the $\mathrm{CO}$ sensing reaction.

the presence of $\mathrm{PdCl}_{2}$. The absorption spectrum of this solution contains a new absorption band at $\sim 500 \mathrm{~nm}$. We propose that these features suggest the formation of a $\left[\operatorname{Pd}(\text { Flav-1 }) \mathrm{L}_{2}\right]^{+}$-type species in solution. It is important to 

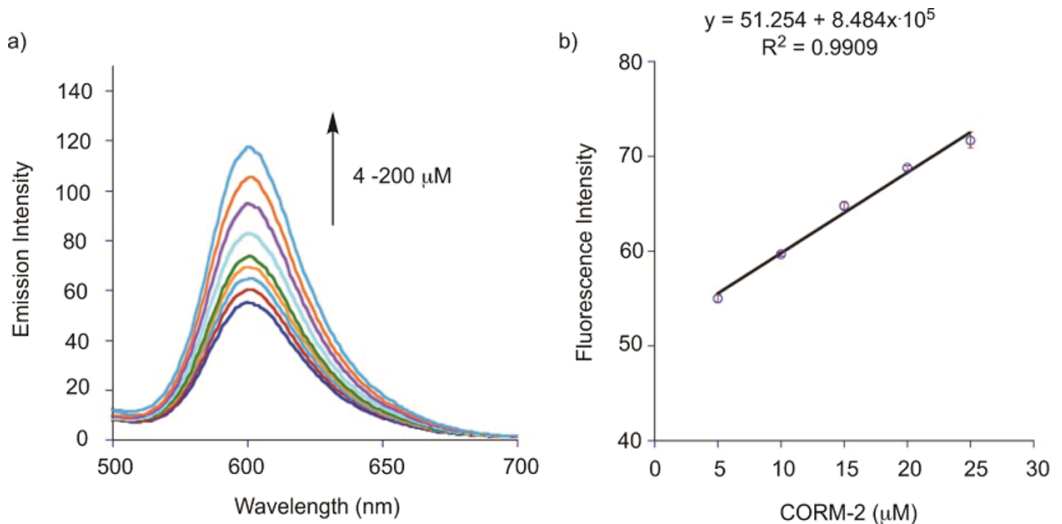

Figure 7. (a) Fluorescent spectral changes produced upon reaction of $1(50 \mu \mathrm{M})$ with $\mathrm{PdCl}_{2}(100 \mu \mathrm{M})$ in DMSO upon addition of different concentrations of CORM-2 $(5-200 \mu \mathrm{M})$. (b) Linear increase in fluorescence intensity produced upon reaction of 1 with $\mathrm{PdCl}_{2}$ upon the addition of CORM-2 $(5-25 \mu \mathrm{M})$. All spectra were measured $15 \mathrm{~min}$ after mixing in DMSO at $37^{\circ} \mathrm{C}\left(\lambda_{\mathrm{ex}}=411 \mathrm{~nm}\right)$.

note that a recently reported series of $\mathrm{Pd}(\mathrm{II})$ complexes of 3hydroxyflavone, $[\mathrm{Pd}(\mathrm{bpy})(3-\mathrm{HFl}-\mathrm{X})] \mathrm{BF}_{4}$, are nonemissive species at room temperature. ${ }^{75,76}$ Emission spectra of solutions of Flav-1 in the presence of CORM-2 show some fluorescence emission quenching but less than that produced in the presence of $\mathrm{PdCl}_{2}$ (Figure 6a). In this regard, we note that $\mathrm{Ru}(\mathrm{II})$ flavonolato species are emissive when excited in the flavonol-related absorption bands. ${ }^{77-81}$ The absorption spectrum of Flav-1 in the presence of CORM-2 contains a new band $>500 \mathrm{~nm}$. The appearance of this band suggests the formation of a $\mathrm{Ru}$ (II) flavonolato complex.

Comparison of the control spectra involving Flav-1 and $\mathrm{PdCl}_{2}$ or CORM-2 to the Tsuji-Trost deprotection reaction mixture of 1 shows that the latter exhibits an intermediate emission quenching relative to those found independently for Flav-1 solutions containing the two heavy metals. An increased absorbance baseline is also present in the CO-sensing deprotection reaction mixture relative to the independent controls. These features suggest that there is likely a mixture of metal flavonolato species, some of which are not soluble in $8 \%$ DMSO in DMEM, in the CO-sensing reaction mixture.

Fluorescence Detection of CO Using 1 in DMSO. As shown in Figure $6 \mathrm{~b}$, when the Tsuji-Trost-type CO sensing reaction of 1 is performed in DMSO the observed emission for Flav-1 is again quenched relative to a standard sample. The absorption features of this solution (Figure 6d) contain characteristics of Flav-1 but also enhanced absorbance at $\sim 500 \mathrm{~nm}$. Comparison of the spectral properties of the CO deprotection reaction mixture of $\mathbf{1}$ in DMSO to independent solutions of Flav-1 in the presence of $\mathrm{PdCl}_{2}$ or CORM-2 (Figures $6 \mathrm{~b}$ and $7 \mathrm{~d}$ ) showed that in DMSO neither heavy metal causes emission quenching or notable changes of the absorption spectrum. This observation suggests that the conditions of the $\mathrm{CO}$-sensing deprotection reaction of $\mathbf{1}$ are necessary to produce the unique spectral features of this mixture. This likely relates to the formation of the Flav-1 anion as a product in the Tsuji-Trost reaction (Scheme 1), which facilitates metal binding. Notably, a positive ion ESI-MS analysis of a CO-sensing deprotection reaction mixture of $\mathbf{1}$ performed following removal of the DMSO and dissolving of the residue in $\mathrm{CH}_{3} \mathrm{CN}$ revealed a cluster associated with the $\mathrm{Pd}(\mathrm{II})$ species $\left[\mathrm{Pd}(\text { Flav-1 })\left(\mathrm{CH}_{3} \mathrm{CN}\right)_{2}\right]^{+}(\mathrm{m} / z$ 475.03; calculated 475.02) (Figure S10). We note that $\mathrm{CO}$ sensing experiments performed using $\mathrm{CO}$ gas in the presence of $\mathrm{PdCl}_{2}$ in DMSO also produced emission quenching and an absorbance spectrum suggestive of $\mathrm{Pd}(\mathrm{II})$ binding to Flav-1 (Figure S11).

Sensitivity Studies. Recognizing that the emission intensity of Flav-1 is affected by interactions with $\mathrm{Ru}(\mathrm{II})$ and $\mathrm{Pd}(\mathrm{II})$, we still estimated a detection limit for $\mathbf{1}$ in DMSO. With increasing concentrations of CORM-2 in the presence of excess $\mathrm{Pd}(\mathrm{II})$, the emission peak for 1 at $465 \mathrm{~nm}$ gradually decreases and the emission peak at $603 \mathrm{~nm}$ for Flav-1 increases in a dose-dependent response to the amount of $\mathrm{CO}$ (Figure 7a). The fluorescence intensity change of Flav-1 at $\sim 600 \mathrm{~nm}$ was found to be linearly proportional to the CORM-2 concentrations in the range of 5-25 $\mu \mathrm{M}$. The $3 \sigma$ method was used to estimate a detection limit $(3.19 \mu \mathrm{M})$.

Selectivity Measurement. The selectivity of the $\mathbf{1}$ for $\mathrm{CO}$ was tested versus anions $\left(\mathrm{Cl}^{-}, \mathrm{Br}^{-}, \mathrm{I}^{-}, \mathrm{AcO}^{-}, \mathrm{HS}^{-}\right)$, amino acids, and biothiols (Glu, Cys, Ser, GSH, and Gly), and $\mathrm{H}_{2} \mathrm{O}_{2}$ was examined in DMSO (Figure 8). Blank solutions of the

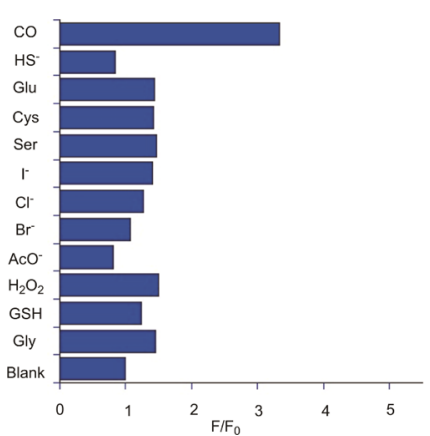

Figure 8. Fluorescent intensity increase at $603 \mathrm{~nm}$ (indicating Flav-1 formation) of a solution of $1(50 \mu \mathrm{M})$ with $\mathrm{PdCl}_{2}(100 \mu \mathrm{M})$ in DMSO upon addition of various analytes $(100 \mu \mathrm{M})$. All spectra were measured $15 \mathrm{~min}$ after mixing in DMSO at $37{ }^{\circ} \mathrm{C}\left(\lambda_{\mathrm{ex}}=411 \mathrm{~nm}\right)$.

probe without analytes, and solutions containing an excess of CORM-2, were used for comparison. Changes in the fluorescence intensity were recorded after $15 \mathrm{~min}$ of incubation of the solutions at $37{ }^{\circ} \mathrm{C}$. As shown in Figure 8, only the addition of CORM-2 induced a significant fluorescence enhancement.

CO Release Reactivity. The coordination of Flav-1 to either $\mathrm{Pd}(\mathrm{II})$ or $\mathrm{Ru}(\mathrm{II})$ will reduce the visible-light induced $\mathrm{CO}$ release reactivity of the flavonol. Specifically, Han, et al. have previously reported that $\mathrm{Pd}(\mathrm{II})$ flavonolato complexes 

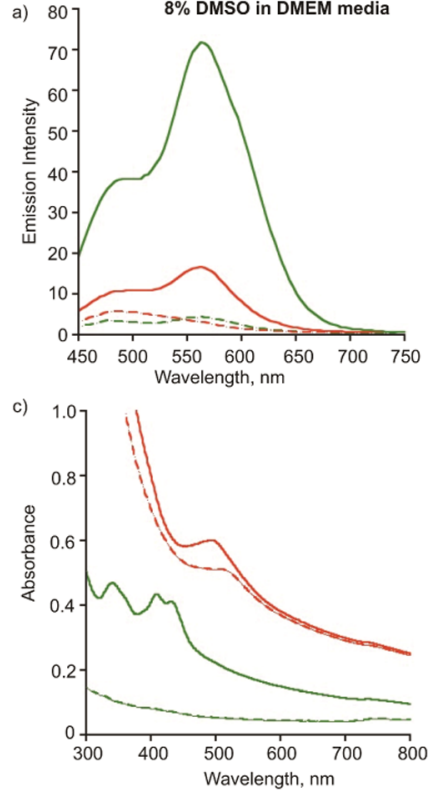

- Flav-1 … Flav-1 + hv $+\mathrm{O}_{2}-1+$ CORM-2 + $\mathrm{PdCl}_{2} \ldots \ldots .1+\mathrm{CORM}_{2} 2+\mathrm{PdCl}_{2}+\mathrm{hv}+\mathrm{O}_{2}$

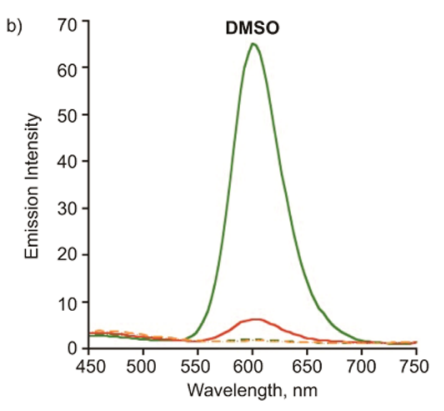

d)

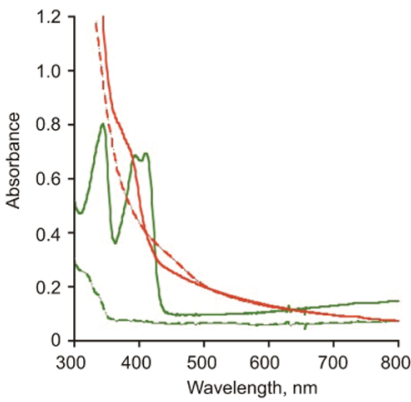

Figure 9. Emission (top) and absorption (bottom) spectra of Flav-1 (50 $\mu \mathrm{M})$ and the Tsuji-Trost CO-sensing reaction of 1 in (a,c) $8 \%$ DMSO in DMEM and $(\mathrm{b}, \mathrm{d})$ DMSO $\left(\lambda_{\mathrm{ex}}=411 \mathrm{~nm}\right)$. Spectra are shown in comparison with those resulting from illumination of the samples with visible light in the presence of $\mathrm{O}_{2}$.

$[\mathrm{Pd}(\mathrm{bpy})(3-\mathrm{HFl}-\mathrm{X})] \mathrm{BF}_{4}$ are unreactive with visible light at ambient temperature. ${ }^{75}$ Saraf, et al. reported that $\mathrm{Ru}(\mathrm{II})$ flavonolato complexes will undergo visible-light-induced $\mathrm{CO}$ release but produce significantly less than one equivalent of $\mathrm{CO}$ due to trapping of the $\mathrm{CO}$ by the $\mathrm{Ru}(\mathrm{II})$ center. $^{79}$ Therefore studies were performed to examine the $\mathrm{CO}$ release reactivity of the CO-sensing deprotection mixture versus control solutions. As shown in Figure 9a, as expected based on our prior work, ${ }^{73}$ illumination of a solution of free Flav-1 in $8 \%$ DMSO in DMEM under air results in bleaching of the emission features in the region of $450-750 \mathrm{~nm}$. The absorbance features of Flav-1 (Figure 9c) in the region of 300-800 $\mathrm{nm}$ also disappear in this reaction, which corresponds to quantitative $\mathrm{CO}$ release and the formation of 3 (Figure 2c). ${ }^{72,73}$ The $\mathrm{CO}$ sensing reaction mixture produced upon treatment of 1 with CORM-2 and $\mathrm{PdCl}_{2}$ also undergoes emission bleaching when exposed to visible light and $\mathrm{O}_{2}$ (Figure 9a). This suggests that the remaining emission signal is likely due to the presence of some free Flav-1 in the mixture. However, the absorption features of the CO-sensing deprotection reaction of $\mathbf{1}$ change only minimally following $30 \mathrm{~min}$ of illumination (Figure 9c), consistent with the majority of the species present in solution being metal complexes of Flav-1 that are unreactive with light.

In DMSO, similar results were found. Free Flav-1 undergoes reaction in the presence of $\mathrm{O}_{2}$ and visible light resulting in bleaching of the emission and loss of the absorption features of the flavonol above $350 \mathrm{~nm}$. These changes are consistent with the quantitative formation of 3 and $\mathrm{CO}$. The CO-sensing reaction mixture of $\mathbf{1}$ undergoes minor bleaching of the emission signal with a modest decrease in the absorption features around $500 \mathrm{~nm}$ (Figure 9b,d). We propose that these spectral changes are associated with the presence of some free Flav-1 in solution along with a majority of metal-complexed Flav-1.
To gain insight into the influence of the individual metal ions on the visible light-induced $\mathrm{CO}$ release reaction from Flav-1, additional control reactions were performed. As shown in Figure 10a, in the presence of CORM-2 in $8 \%$ DMSO in
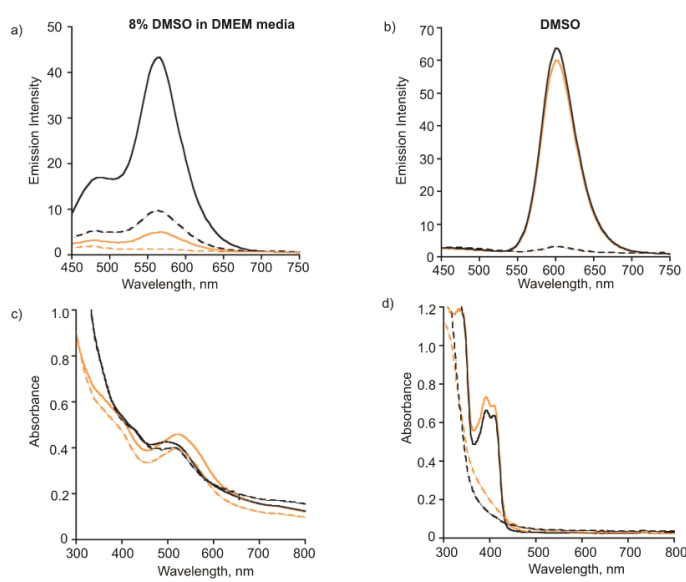

- Flav-1 + CORM-2 …. Flav-1 + CORM-2 +hv $+\mathrm{O}_{2}$ - Flav-1 $+\mathrm{PdCl}_{2} \ldots \ldots$ Flav-1 $+\mathrm{PdCl}_{2}+\mathrm{hv}+\mathrm{O}_{2}$

Figure 10. Emission (top) and absorption (bottom) spectra of solutions of Flav-1 in the presence of $(\mathrm{a}, \mathrm{c})$ CORM-2 or $(\mathrm{b}, \mathrm{d}) \mathrm{PdCl}_{2}$. Spectral changes associated with illumination of the solutions in the presence of $\mathrm{O}_{2}$ are shown.

DMEM, a flavonol emission feature is present at $\sim 560 \mathrm{~nm}$ that undergoes significant bleaching upon exposure to $\mathrm{O}_{2}$ and visible light. The absorption spectra of this solution prior to and post visible light exposure under aerobic conditions are generally similar with a band at $\sim 500 \mathrm{~nm}$. These combined results suggest that the mixture likely contains both free Flav-1 and $\mathrm{Ru}(\mathrm{II})$-coordinated Flav-1. Under the same solution conditions, Flav-1 in the presence of $\mathrm{PdCl}_{2}$ shows significant emission quenching as well as absorption features consistent with metal binding. There is only minimal change upon illumination with visible light in the presence of $\mathrm{O}_{2}$. This 
Scheme 2. Tsuji-Trost-Type CO Sensing Reaction of $1^{a}$
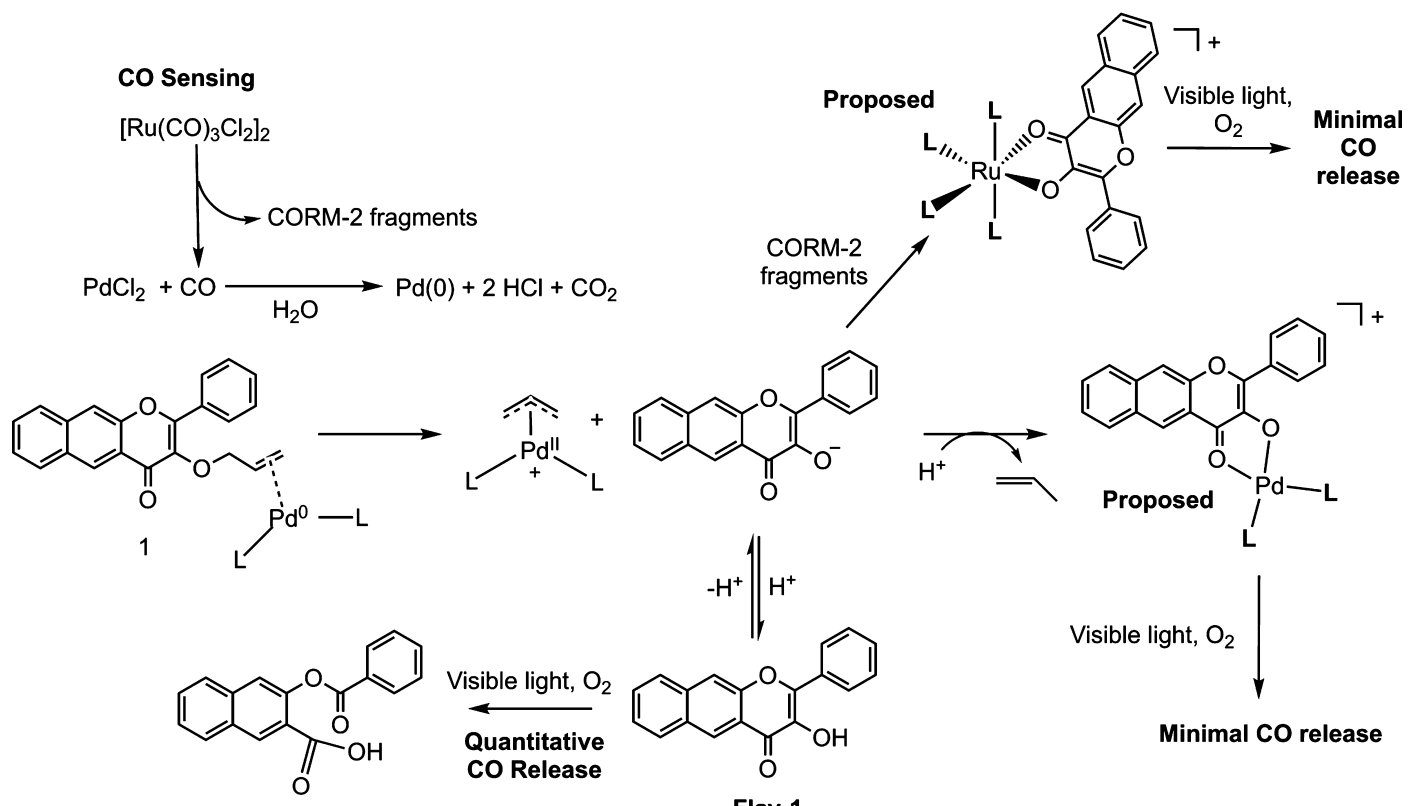<smiles></smiles>
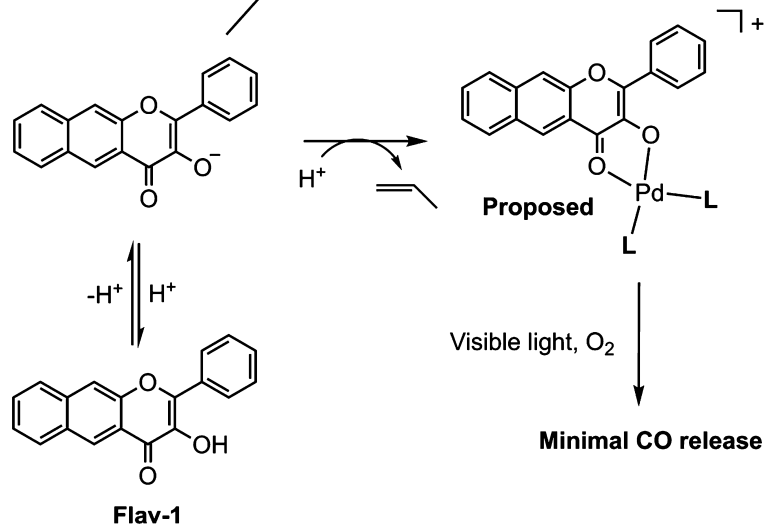

${ }^{a}$ Formation of the Flav-1 anion results in coordination to CORM-2 fragments and $\mathrm{Pd}(\mathrm{II})$. Coordination of the flavonolato anion to these heavy metal ions results in quenching of the flavonol emission and loss of visible light-induced CO release reactivity.

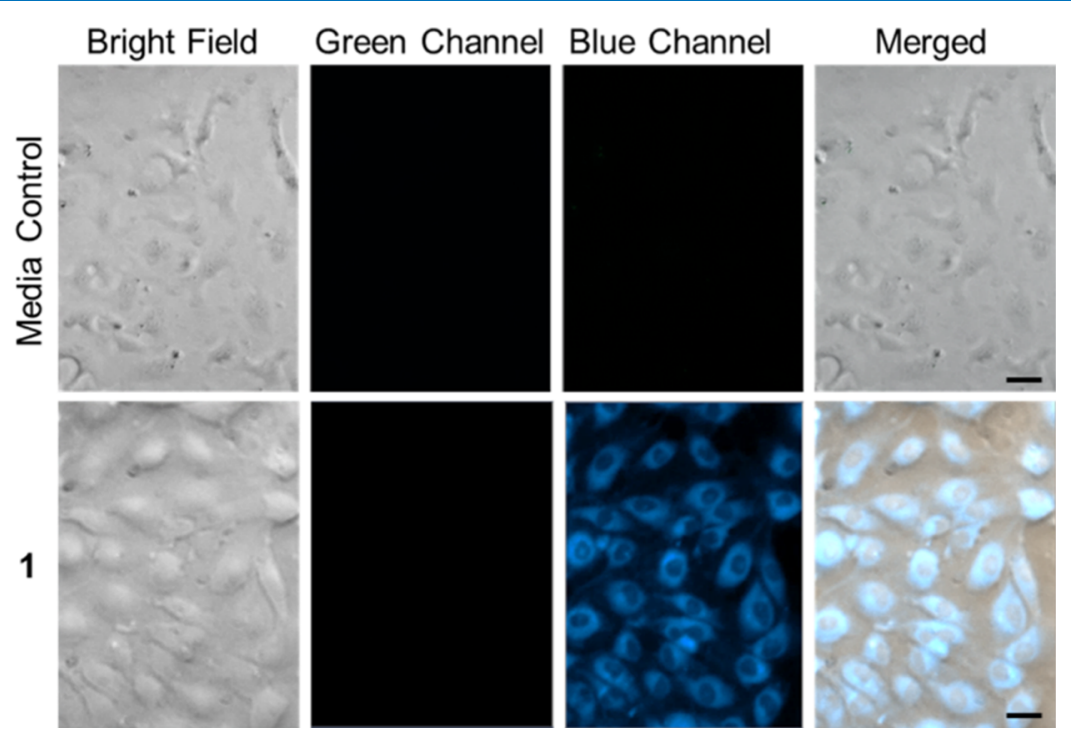

Figure 11. Fluorescence microscopy images of HUVECs incubated for $24 \mathrm{~h}$ in DMEM/F-12K with 1. Row 1: media control cells. Row 2: cells exposed to 1. Blue channel: $\lambda_{\mathrm{ex}}=310-390 \mathrm{~nm}, \lambda_{\mathrm{em}}=420-470 \mathrm{~nm}$. Size of bar $=20 \mu \mathrm{m}$.

indicates that the majority of the Flav-1 is coordinated to $\mathrm{Pd}(\mathrm{II})$. In DMSO, the spectral properties are consistent minimal interaction of Flav-1 with the metal ions. Exposure of DMSO solutions of Flav-1 in the presence of $\mathrm{PdCl}_{2}$ or CORM-2 resulted in bleaching as is typically observed for the free flavonol. These results in DMSO show that only under conditions wherein the flavonol anion forms (e.g., the TsujiTrost CO-sensing deprotection reaction of 1) are metal complexes of Flav-1 formed.

Summary of CO-Sensing Reaction, Metal Coordination, and CO Release. Outlined in Scheme 2 is a summary of the in vitro solution chemistry involved in the $\mathrm{CO}$ sense and release reactivity of $\mathbf{1}$. Key take away points are the following: (1) the Tsuji-Trost CO-sensing deprotection reaction of 1 leads to the formation of the anionic form of Flav-1 which in $8 \%$ DMSO in DMEM or DMSO results in metal coordination as is evidenced by quenching of the emission signal of the flavonol and absorption spectral changes; (2) exposure of Flav1 independently to CORM-2 or $\mathrm{PdCl}_{2}$ in $8 \%$ DMSO in DMEM shows that coordination of the flavonolato anion to $\mathrm{Pd}$ (II) and $\mathrm{Ru}(\mathrm{II})$ occurs under these conditions. In DMSO, metal coordination only occurs in the deprotection reaction of 1. This is due to the need for the anion of Flav-1 to form to enable metal complex formation; (3) visible light induced CO release occurs from free Flav-1 $(<0.25$ equiv based on emission depletion), but only minimally from the metal complexes formed in the reaction mixture. Overall, because metal complexation is predominant in the in vitro $\mathrm{CO}$ sensing 


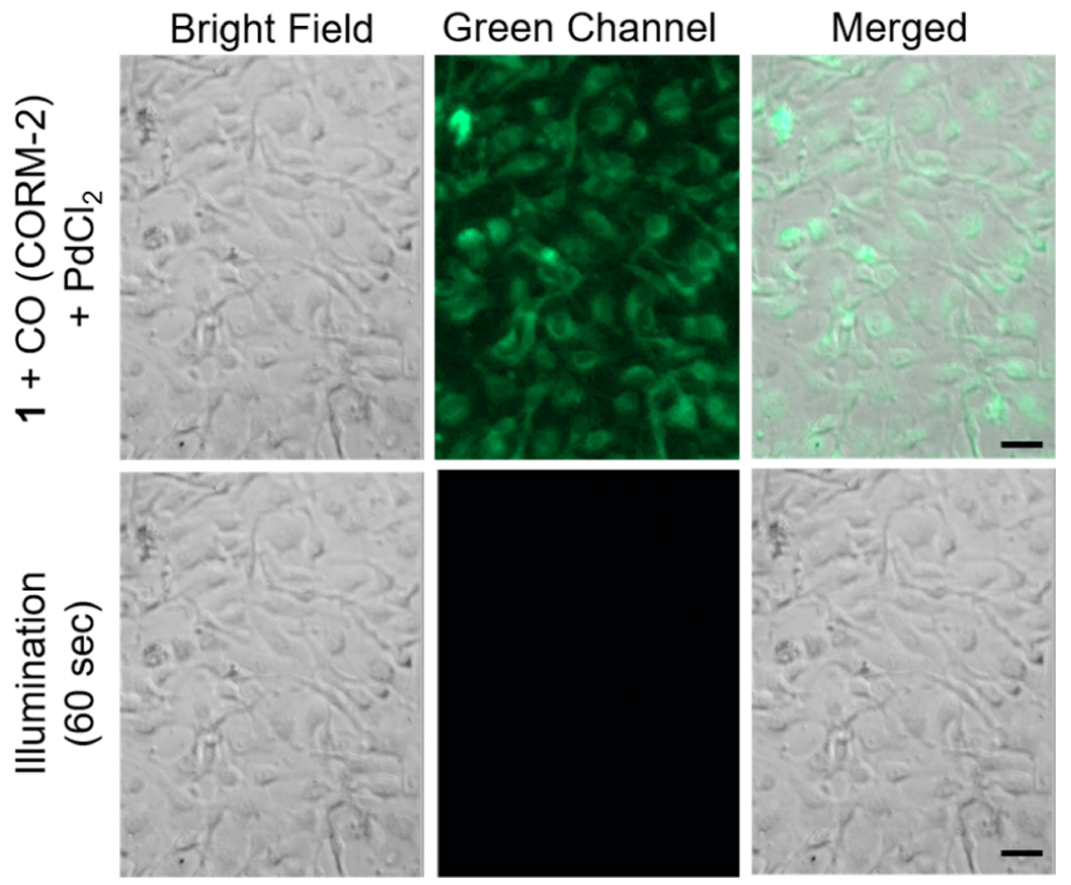

Figure 12. Fluorescent imaging of CO sensing in HUVECs using $1(50 \mu \mathrm{M})$ with $100 \mu \mathrm{M} \mathrm{PdCl}_{2}$ and $500 \mu \mathrm{M}$ CORM-2. Row $1: 1$ incubated for 4 $\mathrm{h}$ followed by the addition of $\mathrm{PdCl}_{2}$ and CORM-2 and additional incubation for $4 \mathrm{~h}$. Row 2: following illumination with 310-390 nm light. Green channel: $\lambda_{\mathrm{ex}}=310-390 \mathrm{~nm}, \lambda_{\mathrm{em}}=500-550 \mathrm{~nm}$. Scale bar $=40 \mu \mathrm{m}$.

deprotection reaction mixtures, replenishment of $\mathrm{CO}$ is not quantitative in simple solution reaction conditions.

Cellular Uptake and CO Sensing. Hypothesizing that the reaction environment in cells may influence the metal coordination properties of Flav-1, we pursued cell-based studies. We began by examining the cytotoxicity of 1 toward HUVECs using an MTT assay. Compound 1 was found to be nontoxic up to $100 \mu \mathrm{M}$ (Figure S11). Flav-1 has been previously reported to be nontoxic to HUVECs up to $50 \mu \mathrm{M}^{74}$

The cellular uptake of $1(50 \mu \mathrm{M})$ was confirmed using fluorescence microscopy. Intracellular uptake of $\mathbf{1}$ was indicated after $24 \mathrm{~h}$ of incubation via detection of its blue fluorescent emission (Figure 11). We next investigated the potential application of this probe for fluorescent imaging of CO in cells. HUVECs were incubated with $1(50 \mu \mathrm{M})$ for 15 min, followed by the addition of $\mathrm{PdCl}_{2}$ (2 equiv) and CORM-2 (10 equiv) and incubation for $4 \mathrm{~h}$ at $37{ }^{\circ} \mathrm{C}$. Note that $\mathrm{PdCl}_{2}$ and CORM-2 are nontoxic at the concentrations employed as determined by an MTT assay (Figure S12). Appearance of a green emission (Figure 12) indicates that free Flav-1 is present and that $\mathbf{1}$ can be used to detect $\mathrm{CO}$ in cell-based experiments. Illumination of the cells $\left(\lambda_{\text {ill }}=488 \mathrm{~nm} ; 42,620 \mathrm{~lx}\right)$ for $60 \mathrm{~s}$ leads to the disappearance of the green emission signal consistent with $\mathrm{CO}$ release (Figure 12). Note that at this point we cannot quantify the amount of $\mathrm{CO}$ generated back into the system as an excess is already present from CORM-2.

We hypothesize that the ability to produce free Flav-1 in cells via the Tsuji-Trost deprotection of $\mathbf{1}$ is due to the presence of competing ligands for the metal ions, especially soft ligands such as those containing sulfur donors. ${ }^{82}$ The binding of Flav-1 to proteins including serum albumin may also limit its interactions with metal ions in the cellular environment. $^{73}$

\section{CONCLUSIONS}

$\mathrm{CO}$ is a signaling molecule of significant current interest for potential therapeutic uses. There is a substantial need to further understand its biological effects at low concentrations in order to leverage this information into the development of potential new applications. An integral part of studying the biology of $\mathrm{CO}$ is being able to detect its presence in biological environments. The goal of analyte replacement probes is to enable the sensing of small molecules such as $\mathrm{CO}$ without perturbing the cellular homeostasis of the analyte. Herein we report the first example of a fluorescent molecular $\mathrm{CO}$ sense and release system. Compound $\mathbf{1}$ is trackable in cells via fluorescence prior to both its $\mathrm{CO}$ sense and $\mathrm{CO}$ release reactions. Under in vitro conditions in $8 \%$ DMSO in DMEM or DMSO, the Tsuji-Trost-type CO sensing reactivity results in significant metal coordination of the Flav-1 product, which minimizes subsequent $\mathrm{CO}$ release reactivity. However, in a cellular environment under conditions wherein there are competing species for binding either the metal ions or Flav1, both $\mathrm{CO}$ sensing and visible light-induced $\mathrm{CO}$ release reactivity are viable. Thus, 1 represents the first trackable analyte replacement photoCORM available for use in living cells. Our future work is directed at examining the biological applications of $\mathbf{1}$ and analogues.

\section{EXPERIMENTAL SECTION}

General Methods. All chemicals and reagents were obtained from commercial sources and used as received unless otherwise noted. Flav-1 was synthesized according to the literature procedure. ${ }^{72}$

Physical Methods. ${ }^{1} \mathrm{H}$ and ${ }^{13} \mathrm{C}\left\{{ }^{1} \mathrm{H}\right\}$ NMR spectra were collected using a Brüker Avance III HD Ascend-500 spectrometer and referenced to residual solvent peak in $\mathrm{CDCl}_{3}\left({ }^{1} \mathrm{H}: 7.26\right.$ (singlet) ppm) or $\mathrm{DMSO}^{-d_{6}}\left({ }^{1} \mathrm{H}: 2.50\right.$ (multiplet) $\mathrm{ppm}) . J$ values are given in hertz. Infrared spectra 
were recorded as potassium bromide pellets using a Shimadzu FTIR-8400. UV-vis spectra were recorded at ambient temperature and $37{ }^{\circ} \mathrm{C}$ using a CARY 50Bio or a HewlettPackard 8453A diode array spectrometer. Fluorescence emission spectra were collected using a Shimadzu RF$530 X P C$ spectrometer in the range of $295-800 \mathrm{~nm}$, with the excitation wavelength corresponding to the absorption maxima of the analyte in the solvent of choice. The spectra were collected using $1.0 \mathrm{~cm}$ quartz cuvettes with excitation and emission slit widths set at 1.5 or $3.0 \mathrm{~nm}$. Mass spectral data for compound characterization were collected at the Mass Spectrometry Facility, University of California, Riverside. ESI-MS spectra of reaction mixtures containing 1, CORM-2, and $\mathrm{PdCl}_{2}$ were collected using a Shimadzu LCMS-2020. A Rayonet photoreactor equipped with RPR-4190A lamps (2450 $\mathrm{lx}$, light intensity) was used for all noncellular light-induced reactions. An Apogee Instruments MQ-500 full spectrum quantum meter was used to determine the photon flux of illumination set ups. Cell imaging was performed using a Zeiss Axio Observer inverted microscope (Carl Zeiss Microscopy, Thornwood, NY) equipped with fluorescence detection.

Synthesis of 1 . Flav-1 (100 mg, $0.347 \mathrm{mmol})$ was combined with $\mathrm{K}_{2} \mathrm{CO}_{3}(169 \mathrm{mg}, 1.04 \mathrm{mmol})$ in DMF (1 $\mathrm{mL}$ ) and stirred for $15 \mathrm{~min}$ at room temperature under nitrogen. Allyl bromide (410 mg, $3.47 \mathrm{mmol}$ ) was then added, and the reaction mixture was stirred overnight at room temperature. The reaction mixture was subsequently heated at $60{ }^{\circ} \mathrm{C}$ and stirred for an additional $3 \mathrm{~h}$. After cooling to room temperature, the mixture was diluted with $10 \mathrm{~mL}$ of water. The organic phase was extracted with ethyl acetate $(3 \times 10 \mathrm{~mL})$, washed with saturated $\mathrm{NaHCO}_{3}(3 \times 10 \mathrm{~mL})$, and dried over $\mathrm{Na}_{2} \mathrm{SO}_{4}$. The filtrate was concentrated under reduced pressure to give a pale-yellow solid ( $80 \mathrm{mg}, 70 \%) .{ }^{1} \mathrm{H}$ NMR $(500 \mathrm{MHz}$, $\left.\mathrm{CDCl}_{3}\right) ; 8.86(\mathrm{~s}, 1 \mathrm{H}), 8.20(\mathrm{~m}, 2 \mathrm{H}), 8.07(\mathrm{~d}, J=8.1 \mathrm{~Hz}, 1 \mathrm{H})$, $8.00(\mathrm{~s}, 1 \mathrm{H}), 7.93(\mathrm{~d}, J=8.1 \mathrm{~Hz}, 1 \mathrm{H}), 7.61(\mathrm{t}, J=7.3 \mathrm{~Hz}, 1 \mathrm{H})$, $7.53(\mathrm{~m}, 4 \mathrm{H}), 5.96(\mathrm{~m}, 1 \mathrm{H}), 5.29(\mathrm{~d}, J=16.9 \mathrm{~Hz}, 1 \mathrm{H}), 5.16$ $(\mathrm{d}, J=10.7 \mathrm{~Hz}, 1 \mathrm{H}), 4.62(\mathrm{~d}, J=6.0 \mathrm{~Hz}, 2 \mathrm{H}) ;{ }^{13} \mathrm{C}\left\{{ }^{1} \mathrm{H}\right\} \mathrm{NMR}$ (500 $\mathrm{MHz}, \mathrm{CDCl}_{3}$ ) 176.2, 157.1, 151.8, 138.8, 136.0, 133.7, $131.4,131.0,130.2,129.7,129.1,128.9,128.6,127.3,127.1$, $126.1,123.2,118.8,114.3,73.7$ (22 signals expected, 20 observed due to the overlap of signals in the aromatic region). UV-Vis (DMSO, nm) $\left(\varepsilon, \mathrm{M}^{-1} \mathrm{~cm}^{-1}\right) 380$ (5600). ESI/APCIMS: (relative intensity) calcd. for $\mathrm{C}_{22} \mathrm{H}_{16} \mathrm{O}_{3}[\mathrm{MH}]^{+}, 329.1178$; found, 329.1173 (100\%). FTIR $\left(\mathrm{KBr}, \mathrm{cm}^{-1}\right) 1399\left(\nu_{\mathrm{C}-\mathrm{O}}\right)$, $1627\left(\nu_{\mathrm{C}=\mathrm{O}}\right)$.

Synthesis of 2. Flav-1 (100 mg, $0.347 \mathrm{mmol})$ and triethylamine $(0.104 \mathrm{~mL})$ were combined in $5 \mathrm{~mL}$ of dry dichloromethane and stirred for $2 \mathrm{~h}$ at room temperature under nitrogen. Allyl chloroformate $(0.111 \mathrm{~mL}, 1.04 \mathrm{mmol})$ was then slowly added. The resulting mixture was stirred overnight at ambient temperature. Water $(5 \mathrm{~mL})$ was then added, and the solution was extracted with dichloromethane (3 $\times 5 \mathrm{~mL}$ ). The combined organic fractions were dried over $\mathrm{Na}_{2} \mathrm{SO}_{4}$, filtered, and concentrated under vacuum to obtain a pale-yellow solid (115 mg, 89\%). ${ }^{1} \mathrm{H}$ NMR (500 MHz, $\left.\mathrm{CDCl}_{3}\right) \delta \mathrm{ppm} 8.88(\mathrm{~s}, 1 \mathrm{H}), 8.08(\mathrm{~d}, J=8.9 \mathrm{~Hz}, 1 \mathrm{H}), 8.04(\mathrm{~s}$, $1 \mathrm{H}), 8.00(\mathrm{~d}, J=5.2 \mathrm{~Hz}, 2 \mathrm{H}), 7.94(\mathrm{~d}, J=8.2 \mathrm{~Hz}, 1 \mathrm{H}), 7.64(\mathrm{t}$, $J=7.55 \mathrm{~Hz}, 1 \mathrm{H}), 7.57(\mathrm{~m}, 4 \mathrm{H}), 5.98(\mathrm{~m}, 1 \mathrm{H}), 5.42(\mathrm{~d}, J=$ $17.5 \mathrm{~Hz}, 1 \mathrm{H}), 5.31(\mathrm{~d}, J=17.5 \mathrm{~Hz}, 1 \mathrm{H}), 4.76(\mathrm{~d}, J=5.5 \mathrm{~Hz}$, $2 \mathrm{H}) ;{ }^{13} \mathrm{C}\left\{{ }^{1} \mathrm{H}\right\}$ NMR $\left(125 \mathrm{MHz}\right.$, DMSO- $\left.d_{6}\right): \delta$ ppm 172.1, $156.7,151.8,151.1,135.7,132.0,131.9,131.5,129.9,129.5$, $129.4,129.3,129.1,128.3,127.4,126.6,126.5,121.8,118.6$, 115.0, 69.3 (23 signals expected, 21 observed due to the overlap of signals in the aromatic region). UV-Vis (DMSO, $\mathrm{nm})\left(\varepsilon, \mathrm{M}^{-1} \mathrm{~cm}^{-1}\right) 330$ (6700), 367 (3690). ESI/APCI-MS: (relative intensity) calcd. for $\mathrm{C}_{22} \mathrm{H}_{14} \mathrm{O}_{5}[\mathrm{MH}]^{+}, 373.1032$; found, $373.1106(100 \%)$. FTIR $\left(\mathrm{KBr}, \mathrm{cm}^{-1}\right) 1624\left(\nu_{\mathrm{C}=\mathrm{O}}\right)$, $1769\left(\nu_{\mathrm{C}=\mathrm{O}}\right)$.

Stability Studies of 1 and 2. Solutions of 1 and 2 (50 $\mu \mathrm{M})$ were prepared in $8 \%$ or $40 \%$ DMSO in PBS ( $10 \mathrm{mM}, \mathrm{pH}$ $=7.4)$, or $8 \%$ DMSO in media, and were incubated at $37{ }^{\circ} \mathrm{C}$ for up to $90 \mathrm{~min}$. Fluorescence spectra were measured every 15 or $30 \mathrm{~min}$ to evaluate sensor hydrolytic stability. The photostability of 1 was evaluated using absorption spectroscopy. In brief, a $100 \mu \mathrm{M}$ solution of $\mathbf{1}$ in DMSO was subjected to illumination ( $\lambda_{\text {ill }}=465 \mathrm{~nm}$; $5972 \mathrm{~lx}$ light intensity) for $1 \mathrm{~h}$. The light stability of 1 was also investigated by ${ }^{1} \mathrm{H}$ NMR in DMSO$d_{6}$ over the course of $24 \mathrm{~h}$ (Figure S9b).

CO-Sensing Reactivity of 1 . To study the CO sensing reactivity of $\mathbf{1}$, fluorescence emission studies were performed using CORM-2 as the CO source. A solution of $1(50 \mu \mathrm{M})$ in 8\% DMSO in DMEM [no fetal bovine serum (FBS)] or neat DMSO was combined with $\mathrm{PdCl}_{2}(100 \mu \mathrm{M}$ in DMSO $)$ and exposed to CO from CORM-2 (500 $\mu \mathrm{M}$ in DMSO). Solutions were incubated at $37{ }^{\circ} \mathrm{C}$ for 90 min after which time emission spectra were measured.

Sensitivity Studies. The detection limit of $\mathbf{1}$ was determined based on the measurement of the fluorescence intensity of 2 upon titration of $50 \mu \mathrm{M}$ of 1 with various concentrations of CORM-2 $(5-200 \mu \mathrm{M})$ in the presence of $100 \mu \mathrm{M} \mathrm{PdCl} l_{2}$ in DMSO incubated at $37^{\circ} \mathrm{C}$ for $15 \mathrm{~min}$. Each data point was measured in triplicate. The linear response was determined from 5 to $25 \mu \mathrm{M}$ of added CORM-2. Average emission values were plotted against CORM-2 to determine the slope. The detection limit was then calculated with the following equation: $\mathrm{DL}=3 \sigma_{\mathrm{bl}} / \mathrm{m}$, where $\sigma_{\mathrm{bl}}$ is the standard deviation of the blank measurements (the blank was measured 10 times) and $m$ is the slope of the linear response.

Selectivity Studies. Selectivity of $\mathbf{1}$ for CO detection was determined by measuring the changes in fluorescence intensity of $50 \mu \mathrm{M}$ solutions of 1 in the presence of $100 \mu \mathrm{M} \mathrm{PdCl}_{2}$ upon addition of various analytes $(100 \mu \mathrm{M})$ at $37^{\circ} \mathrm{C}$ for $15 \mathrm{~min}$. Stock solutions of the analytes $\mathrm{NaOAc}, \mathrm{NaBr}, \mathrm{NaCl}, \mathrm{NaI}$, $\mathrm{Na}_{2} \mathrm{~S}$, Cys, GSH, Ser, Glu, and Gly were prepared in doubly distilled water. $\mathrm{H}_{2} \mathrm{O}_{2}$ (30\%) was used as purchased. Blank solutions of the probes without analytes and solutions with excess of CORM-2 were used for comparison. Changes in the fluorescence intensity were recorded after $15 \mathrm{~min}$ of incubation of the solutions at $37^{\circ} \mathrm{C}$.

Cell Culture Growth Conditions. HUVECs were obtained from ATCC (Manassas, VA) and cultured in F-12K Medium (Gibco) supplemented with $0.03 \mathrm{mg} / \mathrm{mL}$ endothelial cell growth (Sigma-Aldrich), 10\% (v/v) FBS (Caisson Laboratories), $0.1 \mathrm{mg} / \mathrm{mL}$ heparin (Sigma-Aldrich) and 100 $\mathrm{U} / \mathrm{mL}$

Streptomycin-penicillin solution (Gibco). The cells were fed every 3 days with fresh media and subcultured in T-75 flasks at 4000 cells $/ \mathrm{cm}^{2}$. Cells were detached by addition of 3 $\mathrm{mL}$ of Trypsin-EDTA $1 \times$ solution (Caisson Laboratories) for $5 \mathrm{~min}$ and then neutralized with $8 \mathrm{~mL}$ of fresh media. HUVECs were counted using a Cell Countess instrument (ThermoFisher) according to the manufacturer's protocol. Only passages 1-6 were used in experiments.

Cytotoxicity. Three independent biological experiments, each with three technical replicates, were performed for $\mathbf{1}$, CORM-2, and $\mathrm{PdCl}_{2}$ using HUVECs. MTT (3-(4,5- 
dimethylthiazol-2-yl)-2,5-diphenyltetrazolium bromide) (Sigma-Aldrich) was prepared fresh at $5 \mathrm{mg} / \mathrm{mL}$ in sterile PBS solution and filtered through a $0.22 \mu \mathrm{M}$ PES filter. The cells were seeded in 96-well tissue treated plates (Corning, $\mathrm{NY}$ ) at 10,000 cells/well in a volume of $190 \mu \mathrm{L} /$ well and allowed to attach for $24 \mathrm{~h}$. The cells were then treated in triplicate wells with concentrations of 1 ranging from 0.08 to $100 \mu \mathrm{M}$ to a final DMSO concentration that did not exceed $0.4 \%(\mathrm{v} / \mathrm{v})$ and incubated for $24 \mathrm{~h}$. The MTT solution (20 $\mu \mathrm{L}$ ) was then added to each well and incubated for an additional $4 \mathrm{~h}$. The metabolized formazan pellets were solubilized by adding $200 \mu \mathrm{L}$ of DMSO, and the absorption was measured by a Modulus Microplate reader (Turner Biosystems) at 560 and $750 \mathrm{~nm}$ (background). The final results were obtained upon background signal subtraction followed by division of the obtained values by the absorption of the vehicle control (0.4\% DMSO in media) wells. All data were analyzed using GraphPad Prism 7 (La Jolla, California), with values reported as means \pm standard error mean. $\mathrm{IC}_{50}$ values were calculated as nonlinear regression with a bottom constraint of zero.

Cellular Uptake and Fluorescence Imaging of 1 in HUVECs. HUVECs were maintained in culture as described above, then seeded into Millicell E-Z-Slide culture chambers (EMD Millipore, Billerica, MA) at an initial density of $10.0 \times$ $10^{4}$ cells $/ \mathrm{cm}^{3}$ and allowed to adhere to the chamber slides for $24 \mathrm{~h}$. The cells were then treated with 1 for $4 \mathrm{~h}$. The compound was prepared as a $25 \mathrm{mM}$ DMSO stock solution and then diluted to a final concentration of $50 \mu \mathrm{M}$ in the culture, reaching $0.2 \%(\mathrm{v} / \mathrm{v})$ of final DMSO concentration per slide chamber. The culture chambers were gently washed three times with plain culture to remove residual compound. All of the steps described above were performed in the dark with minimal red-light exposure. Images were acquired at $20 \times$ air magnification for 1 (blue channel), $\lambda_{\mathrm{ex}}=310-390 \mathrm{~nm}$, and a detection wavelength range $\lambda_{\mathrm{em}}=420-470 \mathrm{~nm}$. Acquired images were processed by universal adjustment to enhance contrast levels (same settings were applied for all acquired images in each detection channel) using ZEISS ZEN 2.3 Lite software.

CO Detection in Cells. This experiment was performed as described above with the following additions. After $4 \mathrm{~h}$ of incubation with 1 and $\mathrm{PdCl}_{2}$ (2 equiv dissolved in DMSO), CORM-2 (10 equiv dissolved in DMSO immediately prior to the experiment) was added. The slides were then incubated for an additional $4 \mathrm{~h}$. The culture chamber was then gently washed three times with plain culture to remove residual compounds. Images were acquired at $20 \times$ air magnification. For 1 (blue channel), the following excitation and emission parameters were used: $\lambda_{\mathrm{ex}}=310-390 \mathrm{~nm}$ and a detection wavelength range $\lambda_{\text {em }}=420-470 \mathrm{~nm}$. Note that we could not use the GFP excitation and emission parameters that have been typically used for Flav-1 $\mathbf{1}^{72}$ and instead used the following parameters: $\lambda_{\mathrm{ex}}=310-390 \mathrm{~nm}$ and $\lambda_{\mathrm{em}}=500-550 \mathrm{~nm}$ to capture the neutral flavonol emission. Acquired images were processed by universal adjustment to enhance contrast levels (same settings were applied for all acquired images in each detection channel) using ZEISS ZEN 2.3 Lite software.

\section{ASSOCIATED CONTENT}

\section{SI Supporting Information}

The Supporting Information is available free of charge at https://pubs.acs.org/doi/10.1021/acsomega.0c00409.
Characterization data for $\mathbf{1}$ and 2; and toxicity and MS studies (PDF)

Crystallographic data of $\mathrm{C}_{22} \mathrm{H}_{16} \mathrm{O}_{3}$ (CIF)

\section{AUTHOR INFORMATION}

\section{Corresponding Author}

Lisa M. Berreau - Department of Chemistry \& Biochemistry, Utah State University, Logan, Utah 84322-0300, United

States; 이이.orid.0000-0001-9599-5239;

Email: lisa.berreau@usu.edu

\section{Authors}

Marina Popova - Department of Chemistry \& Biochemistry, Utah State University, Logan, Utah 84322-0300, United States

Tatiana Soboleva - Department of Chemistry \& Biochemistry, Utah State University, Logan, Utah 84322-0300, United States; orcid.org/0000-0002-3001-3190

Abby D. Benninghoff - Department of Animal, Dairy and Veterinary Sciences, Utah State University, Logan, Utah 843224815, United States

Complete contact information is available at: https://pubs.acs.org/10.1021/acsomega.0c00409

\section{Author Contributions}

The manuscript was written through contributions of all authors. All authors have given approval to the final version of the manuscript.

\section{Notes}

The authors declare no competing financial interest.

\section{ACKNOWLEDGMENTS}

We thank the NIH (R15GM124596 to L.M.B. and A.D.B.; P20GM103546 to the X-ray core facility at the University of Montana), the NSF (CHE-1429195 for Brüker Avance III HD $500 \mathrm{MHz}$ NMR to USU), the Utah Agricultural Experiment Station (project UTA-1178 to A.D.B.), the American Heart Association (grant 18PRE34030099 to T.S.), and the USU Office of Research and Graduate Studies (PDRF Fellowship to T.S.) for the financial support. We thank Josiah Elsberg for assistance with ESI-MS experiments.

\section{REFERENCES}

(1) Wu, L.; Wang, R. Carbon monoxide: Endogenous production, physiological functions, and pharmacological applications. Pharmacol. Rev. 2005, 57, 585-630.

(2) Ryter, S. W.; Otterbein, L. E. Carbon monoxide in biology and medicine. BioEssays 2004, 26, 270-280.

(3) Motterlini, R.; Otterbein, L. E. The therapeutic potential of carbon monoxide. Nat. Rev. Drug Discovery 2010, 9, 728-743.

(4) Romão, C. C.; Blattler, W. A.; Seixas, J. D.; Bernandes, G. J. L. Developing drug molecules for therapy with carbon monoxide. Chem. Soc. Rev. 2012, 41, 3571-3583.

(5) Ji, X.; Damera, K.; Zhang, Y.; Yu, B.; Otterbien, L. E.; Wang, B. Toward carbon monoxide-based therapeutics: Critical drug delivery and developability issues. J. Pharm. Sci. 2016, 105, 402-416.

(6) Ji, X.; Wang, B. Strategies toward organic carbon monoxide prodrugs. Acc. Chem. Res. 2018, 51, 1377-1385.

(7) Ling, K.; Men, F.; Wang, W.-C.; Zhou, Y.-Q.; Zhang, H.-W.; Ye, D.-W. Carbon monoxide and its controlled release: Therapeutic application, detection, and development of carbon monoxide releasing molecules (CORMs). J. Med. Chem. 2018, 61, 2611-2635.

(8) Ismailova, A.; Kuter, D.; Bohle, D. S.; Butler, I. S. An overview of the potential therapeutic applications of CO-releasing molecules. Bioinorg. Chem. Appl. 2018, 2018, 8547364. 
(9) Hasegawa, U.; van der Vlies, A. J.; Simeoni, E.; Wandrey, C.; Hubbell, J. A. Carbon monoxide-releasing micelles for immunotherapy. J. Am. Chem. Soc. 2010, 132, 18273-18280.

(10) Yang, X.; de Caestecker, M.; Otterbein, L. E.; Wang, B. Carbon monoxide: an emerging therapy for acute kidney injury. Med. Res. Rev. 2019, DOI: $10.1012 /$ med.21650.

(11) Lee, Y.; Kim, J. Simultaneous electrochemical detection of nitric oxide and carbon monoxide generated from mouse kidney organ tissues. Anal. Chem. 2007, 79, 7669-7675.

(12) McLean, S.; Mann, B. E.; Poole, R. K. Sulfite species enhance carbon monoxide release from CO-releasing molecules: Implications for the deoxymyoglobin assay of activity. Anal. Biochem. 2012, 427, $36-40$.

(13) Morimoto, Y.; Durante, W.; Lancaster, D. G.; Klattenhoff, J.; Tittel, F. K. Real-time measurements of endogenous $\mathrm{CO}$ production from vascular cells using an ultrasensitive laser sensor. Am. J. Physiol.: Heart Circ. Physiol. 2001, 280, H483-H488.

(14) Marks, G. S.; Vreman, H. J.; McLaughlin, B. E.; Brien, J. F.; Nakatsu, K. Measurement of endogenous carbon monoxide formation in biological systems. Antioxid. Redox Signaling 2002, 4, 271-277.

(15) Atkin, A. J.; Lynam, J. M.; Moulton, B. E.; Sawle, P.; Motterlini, R.; Boyle, N. M.; Pryce, M. T.; Fairlamb, I. J. S. Modification of the deoxy-myoglobin/carbonmonoxy-myoglobin UV-vis assay for reliable determination of CO-release rates from organometallic carbonyl complexes. Dalton Trans. 2011, 40, 5755-5761.

(16) Esteban, J.; Ros-Lis, J. V.; Martínez-Máñez, R.; Marcos, M. D.; Moragues, M.; Soto, J.; Sancenón, F. Sensitive and selective chromogenic sensing of carbon monoxide by using binuclear rhodium complexes. Angew. Chem., Int. Ed. Engl. 2010, 49, 4934-4937.

(17) Heylen, S.; Martens, J. A. Progress in the chromogenic detection of carbon monoxide. Angew. Chem., Int. Ed. Engl. 2010, 49, 7629-7630.

(18) Rimmer, R. D.; Richter, H.; Ford, P. C. A Photochemical precursor for carbon monoxide release in aerated aqueous media. Inorg. Chem. 2010, 49, 1180-1185.

(19) Marín-Hernández, C.; Toscani, A.; Sancenón, F.; Wilton-Ely, J. D. E. T.; Martínez-Máñez, R. Chromo-fluorogenic probes for carbon monoxide detection. Chem. Commun. 2016, 52, 5902-5911.

(20) Wang, J.; Karpus, J.; Zhao, B. S.; Luo, Z.; Chen, P. R.; He, C. A selective fluorescent probe for carbon monoxide imaging in living cells. Angew. Chem., Int. Ed. Engl. 2012, 51, 9652-9656.

(21) Michel, B. W.; Lippert, A. R.; Chang, C. J. A Reaction-based fluorescent probe for selective imaging of carbon monoxide in living cells using a palladium-mediated carbonylation. J. Am. Chem. Soc. 2012, 134, 15668-15671.

(22) Zheng, K.; Lin, W.; Tan, L.; Chen, H.; Cui, H. A unique carbazole-coumarin fused two-photon platform: development of a robust two-photon fluorescent probe for imaging carbon monoxide in living tissues. Chem. Sci. 2014, 5, 3439-3448.

(23) Li, Y.; Wang, X.; Yang, J.; Xie, X.; Li, M.; Niu, J.; Tong, L.; Tang, B. Fluorescent probe based on azobenzene-cyclopalladium for the selective imaging of endogenous carbon monoxide under hypoxia conditions. Anal. Chem. 2016, 88, 11154-11159.

(24) Liu, K.; Kong, X.; Ma, Y.; Lin, W. Rational design of a robust fluorescent probe for the detection of endogenous carbon monoxide in living zebrafish embryos and mouse tissue. Angew. Chem., Int. Ed. 2017, 56, 13489-13492.

(25) Liu, K.; Kong, X.; Ma, Y.; Lin, W. Preparation of a nile red-Pdbased fluorescent $\mathrm{CO}$ probe and its imaging applications in vitro and in vivo. Nat. Protoc. 2018, 13, 1020-1033.

(26) Sun, M.; Yu, H.; Zhang, K.; Wang, S.; Hayat, T.; Alsaedi, A.; Huang, D. Palladacycle based fluorescence turn-on probe for sensitive detection of carbon monoxide. ACS Sens. 2018, 3, 285-289.

(27) Xu, S.; Liu, H.-W.; Yin, X.; Yuan, L.; Huan, S.-Y.; Zhang, X.-B. A cell membrane-anchored fluorescent probe for monitoring carbon monoxide release from living cells. Chem. Sci. 2019, 10, 320-325.

(28) Madea, D.; Martínek, M.; Muchová, L.; Váňa, J.; Vítek, L.; Klán, P. Structural modifications of nile red carbon monoxide fluorescent probe: Sensing mechanism and applications. J. Org. Chem. 2020, 85, 3473.

(29) Pal, S.; Mukherjee, M.; Sen, B.; Mandal, S. K.; Lohar, S.; Chattopadhyay, P.; Dhara, K. A new fluorogenic probe for the selective detection of carbon monoxide in aqueous medium based on $\operatorname{Pd}(0)$ mediated reaction. Chem. Commun. 2015, 51, 4410-4413.

(30) Yan, J.; Zhu, J.-Y.; Tan, Q.-F.; Zhou, L.-F.; Yao, P.-F.; Lu, Y.-T.; Tan, J.-H.; Zhang, L. Development of a colorimetric and NIR fluorescent dual probe for carbon monoxide. RSC Adv. 2016, 6, 66373-65376.

(31) Feng, W.; Liu, D.; Feng, S.; Feng, G. Readily available fluorescent probe for carbon monoxide imaging in living cells. Anal. Chem. 2016, 88, 10648-10653.

(32) Feng, S.; Liu, D.; Feng, W.; Feng, G. Allyl fluorescein ethers as promising fluorescent probes for carbon monoxide imaging in living cells. Anal. Chem. 2017, 89, 3754-3760.

(33) Feng, W.; Liu, D.; Zhai, Q.; Feng, G. Lighting up carbon monoxide in living cells by a readily available and highly sensitive colorimetric and fluorescent probe. Sens. Actuators, B 2017, 240, 625630.

(34) Feng, W.; Hong, J.; Feng, G. Colorimetric and ratiometric fluorescent detection of carbon monoxide in air, aqueous solution, and living cells by a naphthalimide-based probe. Sens. Actuators, B 2017, 251, 389-395.

(35) Feng, W.; Feng, G. A readily available colorimetric and nearinfrared fluorescent turn-on probe for detection of carbon monoxide in living cells and animals. Sens. Actuators, B 2018, 255, 2314-2320.

(36) Wang, Z.; Geng, Z.; Zhao, Z.; Sheng, W.; Liu, C.; Lv, X.; He, Q.; Zhu, B. A highly specific and sensitive ratiometric fluorescent probe for carbon monoxide and its bioimaging applications. New J. Chem. 2018, 42, 14417-14423.

(37) Tian, X.; Liu, X.; Wang, A.; Lau, C.; Lu, J. Bioluminescence imaging of carbon monoxide in living cells and nude mice based on $\mathrm{Pd}^{0}$-mediated Tsuji-Trost reaction. Anal. Chem. 2018, 90, 59515958.

(38) Wang, J.; Li, C.; Chen, Q.; Li, H.; Zhou, L.; Jiang, X.; Shi, M.; Zhang, P.; Jiang, G.; Tang, B. Z. An easily available ratiometric reaction-based AIE probe for carbon monoxide light-up imaging. Anal. Chem. 2019, 91, 9388-9392.

(39) Gong, S.; Hong, J.; Zhou, E.; Feng, G. A near-infrared fluorescent probe for imaging endogenous carbon monoxide in living systems with a large Stokes shift. Talanta 2019, 201, 40-45.

(40) Wang, Z.; Zhao, Z.; Liu, C.; Geng, Z.; Duan, Q.; Jia, P.; Li, Z.; Zhu, H.; Zhu, B.; Sheng, W. A long-wavelength ultrasensitive colorimetric fluorescent probe for carbon monoxide detection in living cells. Photochem. Photobiol. Sci. 2019, 18, 1851-1857.

(41) Deng, Y.; Hong, J.; Zhou, E.; Feng, G. Near-infrared fluorescent probe with a super large Stokes shift for tracking $\mathrm{CO}$ in living systems based on a novel coumarin-dicyanoisophorone hybrid. Dyes Pigm. 2019, 170, 107634.

(42) Wang, Z.; Zhao, Z.; Wang, R.; Yuan, R.; Liu, C.; Duan, Q.; Zhu, W.; Li, X.; Zhu, B. A mitochondria-targetable colorimetric and far-red fluorescent probe for the sensitive detection of carbon monoxide in living cells. Anal. Methods 2019, 11, 288-295.

(43) Fang, W.-L.; Tang, Y.-J.; Guo, X.-F.; Wang, H. A fluorescent probe for carbon monoxide based on allyl ether rather than allyl ester: A practical strategy to avoid the interference of esterase in cell imaging. Talanta 2019, 205, 120070.

(44) Zhang, W.; Wang, Y.; Dong, J.; Zhang, Y.; Zhu, J.; Gao, J. Rational design of stable near-infrared cyanine-based probe with remarkable large Stokes Shift for monitoring carbon monoxide in living cells and in vivo. Dyes Pigm. 2019, 171, 107753.

(45) Zhou, E.; Gong, S.; Feng, G. Rapid detection of CO in vitro and in vivo with a ratiometric probe showing near-infrared turn-on fluorescence, large Stokes shift, and high signal-to-noise ratio. Sens. Actuators, B 2019, 301, 127075.

(46) Zhou, E.; Gong, S.; Hong, J.; Feng, G. Development of a new ratiometric probe with near-infrared fluorescence and a large Stokes 
shift for detection of gasotransmitter CO in living cells. Spectrochim. Acta, Part A 2020, 227, 117657.

(47) Song, F.; Garner, A. L.; Koide, K. A Highly sensitive fluorescent sensor for palladium based on the allylic oxidative insertion mechanism. J. Am. Chem. Soc. 2007, 129, 12354-12355.

(48) Garner, A. L.; Koide, K. Studies of a fluorogenic probe for palladium and platinum leading to a palladium-specific detection method. Chem. Commun. 2009, 45, 86-88.

(49) Santra, M.; Ko, S.-K.; Shin, I.; Ahn, K. H. Fluorescent detection of palladium species with an $\mathrm{O}$-propargylated fluorescein. Chem. Commun. 2010, 46, 3964-3966.

(50) Dhara, K.; Lohar, S.; Patra, A.; Roy, P.; Saha, S. K.; Sadhukhan, G.; Chattopadhyay, P. A new lysosome-targetable turn-on fluorogenic probe for carbon monoxide imaging in living cells. Anal. Chem. 2018, 90, 2933-2938.

(51) Chattopadhyay, B.; Lohar, S.; Patra, A.; Ahmmed, E.; Mandal, S. K.; Bhakta, J. N.; Dhara, K.; Chattopadhyay, P. A naphthalimidebased fluorescence "turn-on" chemosensor for highly selective detection of carbon monoxide: imaging applications in living cells. New J. Chem. 2018, 42, 13497-13502.

(52) Feng, W.; Feng, S.; Feng, G. A fluorescent ESIPT probe for imaging CO-releasing molecule-3 in living systems. Anal. Chem. 2019, 91, 8602-8606.

(53) Yuan, Z.; Yang, X.; De La Cruz, L. K.; Wang, B. Nitro reduction-based fluorescent probes for carbon monoxide require reactivity involving a ruthenium carbonyl moiety. Chem. Commun. 2020, 56, 2190-2193.

(54) Wang, Z.; Liu, C.; Wang, X.; Duan, Q.; Jia, P.; Zhu, H.; Li, Z.; Zhang, X.; Ren, X.; Zhu, B.; Sheng, W. A metal-free near-infrared fluorescent probe for tracking the glucose-induced fluctuations of carbon monoxide in living cells and zebrafish. Sens. Actuators, B 2019, 291, 329-336.

(55) Tang, Z.; Song, B.; Ma, H.; Luo, T.; Guo, L.; Yuan, J. Mitochondria-targetable ratiometric time-gated luminescence probe for carbon monoxide based on lanthanide complexes. Anal. Chem. 2019, 91, 2939-2946.

(56) Zhang, C.; Xie, H.; Zhan, T.; Zhang, J.; Chen, B.; Qian, Z.; Zhang, G.; Zhang, W.; Zhou, J. A new mitochondrion targetable fluorescent probe for carbon monoxide-specific detection and live cell imaging. Chem. Commun. 2019, 55, 9444-9447.

(57) Toscani, A.; Marín-Hernández, C.; Robson, J. A.; Chua, E.; Dingwall, P.; White, A. J. P.; Sancenón, F.; de la Torre, C.; MartínezMáñez, R.; Wilton-Ely, J. D. E. T. Highly sensitive and selective molecular probes for chromo-fluorogenic sensing of carbon monoxide in air, aqueous solution and cells. Chem.-Eur. J. 2019, 25, 20692081.

(58) Dulebohn, J. I.; Haefner, S. C.; Berglund, K. A.; Dunbar, K. R. Reversible carbon monoxide addition to sol-gel derived composite films containing a cationic rhodium(I) complex: towards the development of a new class of molecule-based carbon monoxide sensors. Chem. Mater. 1992, 4, 506-508.

(59) Haefner, S. C.; Dunbar, K. R.; Bender, C. Reversible carbon monoxide reactions of cationic rhodium(I) and -(II) complexes. J. Am. Chem. Soc. 1991, 113, 9540-9553.

(60) Bedford, R. B.; Hill, A. F.; Jones, C.; White, A. J. P.; Williams, D. J.; Wilton-Ely, J. D. E. T. Phosphaalkyne hydrometalation: Synthesis and reactivity of the complexes $\left[\mathrm{Ru}\left(\mathrm{PCHCMe}_{3}\right) \mathrm{Cl}(\mathrm{CA})\right.$ $\left.\left(\mathrm{PPh}_{3}\right)_{2}\right](\mathrm{A}=\mathrm{O}, \mathrm{S})$. Organometallics 1998, 17, 4744-4753.

(61) Benito-Gargorri, D.; Puchberger, M.; Mereiter, K.; Kirchner, K. Stereospecific and reversible $\mathrm{CO}$ binding at iron pincer complexes. Sensitive and selective chromogenic sensing of carbon monoxide by using binuclear rhodium complexes. Angew. Chem., Int. Ed. 2008, 47, 9142-9145.

(62) Esteban, J.; Ros-Lis, J. V.; Martínez-Máñez, R.; Marcos, M. D.; Moragues, M.; Soto, J.; Sancenón, F. Sensitive and selective chromogenic sensing of carbon monoxide by using binuclear rhodium complexes. Angew. Chem., Int. Ed. 2010, 49, 4934-4937.
(63) Marín-Hernández, C.; Toscani, A.; Sancenón, F.; Wilton-Ely, J. D. E. T.; Martínez-Máñez, R. Chromo-fluorogenic probes for carbon monoxide detection. Chem. Commun. 2016, 52, 5902-5911.

(64) Halter, O.; Fernandez, I.; Fernández, H. Fine-tuning the fluorescence gain of FRET-type (Bodipy)(Bodipy')-NHC-iridium complexes for $\mathrm{CO}$ detection with a large virtual stokes shift. Chem.Eur. J. 2017, 23, 711-719.

(65) Bergmann, M.; Egert, M.; Plenio, H. Malodorogenic sensing of carbon monoxide. Chem.-Eur. J. 2017, 23, 13328-13331.

(66) Bergmann, M.; Plenio, H. Giving an odor to carbon monoxide: malodorogenic sensing of carbon monoxide via $[\mathrm{IrCl}(\mathrm{cod})(\mathrm{NHC})]$ complexes. Eur. J. Inorg. Chem. 2018, 2018, 2054-2059.

(67) de La Torre, C.; Toscani, A.; Marín-Hernández, C.; Robson, J. A.; Terencio, M. C.; White, A. J. P.; Alcaraz, M. J.; Wilton-Ely, J. D. E. T.; Martínez-Máñez, R.; Sancenón, F. Ex vivo tracking of endogenous CO with a ruthenium(II) complex. J. Am. Chem. Soc. 2017, 139, 18484-18487.

(68) Southam, H. M.; Smith, T. W.; Lyon, R. L.; Liao, C.; Trevitt, C. R.; Middlemiss, L. A.; Cox, F. L.; Chapman, J. A.; El-Khamisy, S. F.; Hippler, M.; Williamson, M. P.; Henderson, P. J. F.; Poole, R. K. A thiol-reactive $\mathrm{Ru}(\mathrm{II})$ ion, not $\mathrm{CO}$ release, underlies the potent antimicrobial and cytotoxic properties of CO-releasing molecule-3. Redox Biol. 2018, 18, 114-123.

(69) Aki, T.; Unuma, K.; Noritake, K.; Hirayama, N.; Funakoshi, T.; Uemura, K. Formation of high molecular weight p62 by CORM-3. PLoS One 2019, 14, No. e0210474.

(70) Steiger, A. K.; Pardue, S.; Kevil, C. G.; Pluth, M. D. Selfimmolative thiocarbamates provide access to triggered $\mathrm{H}_{2} \mathrm{~S}$ donors and analyte replacement fluorescent probes. J. Am. Chem. Soc. 2016, $138,7256-7259$.

(71) Xu, H.; Xu, H.; Ma, S.; Chen, X.; Huang, L.; Chen, J.; Gao, F.; Wang, R.; Lou, K.; Wang, W. Analyte regeneration fluorescent probes for formaldehyde enabled by regiospecific formaldehyde-induced intramolecularity. J. Am. Chem. Soc. 2018, 140, 16408-16412.

(72) Anderson, S. N.; Richards, J. M.; Esquer, H. J.; Benninghoff, A. D.; Arif, A. M.; Berreau, L. M. A structurally-tunable 3-hydroxyflavone motif for visible light-induced carbon monoxide-releasing molecules (CORMs). ChemistryOpen 2015, 4, 590-594.

(73) Popova, M.; Soboleva, T.; Arif, A. M.; Berreau, L. M. Properties of a flavonol-based photoCORM in aqueous buffered solutions: influence of metal ions, surfactants and proteins on visible lightinduced CO release. RSC Adv. 2017, 7, 21997-22007.

(74) Soboleva, T.; Esquer, H. J.; Anderson, S. N.; Berreau, L. M.; Benninghoff, A. D. Mitochondrial-localized versus cytosolic intracellular CO-releasing organic photoCORMs: Evaluation of CO effects using bioenergetics. ACS Chem. Biol. 2018, 13, 2220-2228.

(75) Han, X.; Whitfield, S.; Cotten, J. Synthesis, characterization, and CO-releasing property of palladium(II) bipyridine flavonolate complexes. Transition Met. Chem. 2020, DOI: 10.1007/s11243-01900373-9.

(76) Han, X. Private communication.

(77) Han, X.; Kumar, M. R.; Hoogerbrugge, A.; Klausmeyer, K. K.; Ghimire, M. M.; Harris, L. M.; Omary, M. A.; Farmer, P. J. Mechanistic investigations of photoinduced oxygenation of $\mathrm{Ru}(\mathrm{II})$ bis-bipyridyl flavonolato complexes. Inorg. Chem. 2018, 57, 24162424.

(78) Han, X.; Klausmeyer, K. K.; Farmer, P. J. Characterization of the initial intermediate formed during photoinduced oxygenation of the ruthenium(II) bis(bipyridyl)flavonolate complex. Inorg. Chem. 2016, 55, 7320-7322.

(79) Saraf, S. L.; Fish, T. J.; Benninghoff, A. D.; Buelt, A. A.; Smith, R. C.; Berreau, L. M. Photochemical reactivity of $\mathrm{Ru}^{\mathrm{II}}\left(\eta^{6}-p\right.$-cymene $)$ flavonolato compounds. Organometallics 2014, 33, 6341-6351.

(80) Kurzwernhart, A.; Kandioller, W.; Bächler, S.; Bartel, C.; Martic, S.; Buczkowska, M.; Mühlgassner, G.; Jakupec, M. A.; Kraatz, H.-B.; Bednarski, P. J.; Arion, V. B.; Marko, D.; Keppler, B. K.; Hartinger, C. G. Structure-activity relationships of targeted $\mathrm{Ru}(\mathrm{II})$ $\left(\mathrm{n}^{6}\right.$-p-cymene) anticancer complexes with flavonol-deried ligands. J. Med. Chem. 2012, 55, 10512-10522. 
(81) Kurzwernhart, A.; Kandioller, W.; Enyedy, É. A.; Novak, M.; Jakupec, M. A.; Keppler, B. K.; Hartinger, C. G. 3-Hydroxyflavone and 3-hydroxyquinolinones: Structure-activity relationships and stability studies on $\mathrm{Ru}(\mathrm{II})$ (arene) anticancer complexes with biologically active ligands. Dalton Trans. 2013, 42, 6193-6202.

(82) McLaughlin, M. P.; Darrah, T. H.; Holland, P. L. Palladium(II) and platinum(II) bind strongly to an engineered blue copper protein. Inorg. Chem. 2011, 50, 11294-11296. 